\title{
Investigation of Sustainable and Affordable Housing Policy Principles and Formulation Adoptable in Kabul City, Afghanistan
}

\author{
Mohammad Saraj Sharifzai ${ }^{1}$, Keisuke Kitagawa ${ }^{2}$, Ahmad Javid Habib ${ }^{3}$, Mohammad Kamil Halimee ${ }^{4}$ \& Daishi \\ Sakaguchi $^{5}$ \\ ${ }^{1}$ Department of Scientific Engineering Simulation, Nagoya Institute of Technology, Japan \\ ${ }^{2}$ Department of Scientific Engineering Simulation, Nagoya Institute of Technology, Japan \\ ${ }^{3}$ Student, Department of Urban Engineering, School of Engineering, University of Tokyo, Tokyo, Japan \\ ${ }^{4}$ Department of Scientific Engineering Simulation, Nagoya Institute of Technology, Japan \\ ${ }^{5}$ Department of Scientific Engineering Simulation, Nagoya Institute of Technology, Japan \\ Correspondence: Mohammad Saraj Sharifzai, Department of Scientific Engineering Simulation, Nagoya Institute \\ of Technology, Japan. Tel: 81-90-4262-5050. E-mail: sarajsharifzai@yahoo.com; sarajsharifzai@gmail.com
}

Received: August 14, 2015 Accepted: September 9, 2015 Online Published: March 30, 2016

doi:10.5539/jsd.v9n2p93 URL: http://dx.doi.org/10.5539/jsd.v9n2p93

\begin{abstract}
In recent architectural and environmental research, principles of sustainability and affordability with respect to economic, environmental and social policies have been widely discussed on a worldwide scale. Urban housing planning can play a very important role in achieving sustainable growth and development by integrating 'sustainable development principles' into urban planning strategies, policies, programs and projects. In addition, affordability is at the heart of households' efforts to improve their housing situation. It has been widely recognized that employment, income generation and access to housing are highly interrelated internationally. Housing affordability has become one of the dominant research topics in recent years. However, few studies have been undertaken to test the compatibility between affordable housing and sustainable housing. Sustainable and affordable development of housing, a basic unit of human settlement, is also a crucial component of social development in one community. It plays an important role in achieving sustainable development. The concept of shelter differs from individual to individual depending on culture, tradition, profession and way of living. Besides being a basic necessity, it is also a source of identity that has a significant effect on the overall psychological well being of the inhabitants. Sustainable-affordable habitat can be described as a way of developing and maintaining a living environment supporting human health (both physical and psychological), satisfying shelter needs, and protecting and preserving nature for future generations. This paper introduces a conceptual framework for defining housing problems from the perspective of the support of beneficiaries, and it seeks to analyze the effectiveness of Afghan national development policies in facilitating sustainable-affordable habitat across the country. The framework shows the interdependency of different aspects of sustainability in the process of housing development. It also sets out strategies and identifies policy initiatives required to realize the goal of sustainable-affordable habitat in Kabul. The principles developed in this paper can be generally applied and adopted in Afghanistan, a country that is less developed economically.
\end{abstract}

A fundamental understanding of these two issues is necessary to develop successful examples of this form of accommodation. Because of three decades of socioeconomic and political instability in Afghanistan, the country does not have a national housing policy. This paper tries to create the foundation for an Afghan national housing policy. This research reveals that the majority of Kabul residents are low- or medium-income earners that cannot afford housing produced under market conditions. This paper aims to identify suitable built forms for housing that is both affordable and environmentally sustainable. A series of case studies were conducted to investigate some of the best international forms to be adopted in practices at the national scale. The research is conducted qualitatively, and the required data is acquired from a site survey of Kabul, in addition to data from new World Bank and JICA (Japan International Cooperation Agency) Master Plans. The result was the development of a framework that enables the assessment of the overall performance of various types of housing development. There is very little evidence that the present approach of housing provision linked to the vagaries of market forces has provided affordable housing, especially for government employees and low-income citizens. There is a need to incorporate 
social housing into a policy to assist people who cannot provide their own housing needs.

Keywords: housing policy, affordability, social housing, housing provision, environmental sustainability and conceptual principles for adaptation in Afghanistan

\section{Introduction}

Sustainable and affordable housing have long been important planning and design concerns in large urban areas and around the peripheries of major cities where population growth has led to an increasing demand for decent housing environments. Housing embodies many concepts. such as comfort, safety and identity. Above all, housing has central importance to everyone's quality of life and health with considerable economic, social, cultural and personal significance. It is also a critical component in the social and economic fabric of all nations. No country is yet satisfied that adequate housing has been delivered to the various economic groups that make up its populace.

It is estimated that there are more than 100 million homeless and about one billion people inadequately housed throughout the world (UNCHS 1996). Although they constitute one quarter of all humanity, only a small fraction lives in the industrialized countries. Developing countries such as Afghanistan suffer the most acute housing problems. About one third or more of their total population is homeless [15], [18]. The reasons for and nature of these problems differ from country to country depending on local social, economic and political contexts. The housing problems of low-income countries differ greatly from those experienced in developed economies; rural and urban housing also exhibit their own peculiar differences.

This paper attempts to develop a conceptual framework for sustainable-affordable housing for urban areas in Afghanistan. Kabul is a city with a long history. After becoming the capital of Afghanistan in 1775, the population and territory of the city expanded steadily. The city was beautifully shaped with plenty of trees. Since the beginning of the 20th century, the city has experienced rapid growth. From the 1970s to the end of the century, development of the city has been sluggish due to various political conflicts. The existing infrastructure was also severely damaged during this period. Since 2001, the government and people of Afghanistan have been making efforts for the reconstruction of Kabul. International donors are also working for rehabilitation and reconstruction of the capital city of Afghanistan. However, there is no common vision and/or direction of the reconstruction and future development of Kabul City, as the city has no working master plan. The absence of a city master plan is affecting the lives of citizens and economic activities of enterprises, because of the unpredictable status of their lands and properties for living and business operation. [5], [6]

In recent years, more than three million refugees returned to the country, with the majority settling in the country's urban centers, primarily in the capital city of Kabul. Kabul is a powerful magnet for Afghans looking for security and a better life after decades of civil war, particularly for refugees returning from abroad. Today, the city has a population of more than 4 million, with impoverished residents filling war-devastated sections of the city and constructing new dwellings higher and higher on the surrounding hillsides. It appears that the growth of Kabul will continue unabated in the next 10-15 years. Rapid urbanization is also resulting in dangerous pressures on antiquated infrastructure that cannot meet the water, electricity and other requirements of large portions of the population, while problems of health and hygiene associated with high-density settlements are common. However, the $\$ 8$ million aid project is not connected to a water supply and there are concerns it is too far from Kabul for residents to find work. In order to overcome problems like these, creation of a sustainable and affordable national housing policy seems to be one of the clear necessities. This research tries to provide a new gate towards creation of such a policy, while future research will try to create a skeleton for the policy, in the hope that finally Afghans will have their own sustainable and affordable national housing policy. [5], [6]

This study starts with an overview of sustainable and affordable housing policy in Afghanistan at the national level, which is intended to sketch out some of the issues that may influence action at the lower levels.

Most teachers and government employees in Kabul could not find shelter through the construction of shelter made of permanent materials. The population living in tents is estimated at 10,000 people, or about 4,000 households. An additional 5,000 people are thought to be living in the ruins of destroyed buildings. Given the extraordinary number of people who have been migrating to Kabul over the years, and taking into account the past political instability of the country, it is remarkable that only about $0.5 \%$ of the population is currently living in temporary shelter. While the informal land development process has often been messy, the overall outcome is certainly positive if one considers that the only possible alternative to informal land development would have been for migrants to live in temporary shelters in refugee camps waiting for the government's orderly resettlement plans to materialize. [5] 
There was a harmony between people's needs and the physical characteristics of the house. In urban houses this was mostly the same, but a new residential type appeared, in which living spaces were categorized according to their general functions. Spatial arrangement, together with plan layout and proportions, facilitated the limited potential for varied lifestyles. In the contemporary period, apartment buildings (most of which were made by the Russian system name of Makroryan) became prevalent. In this new type of residence, the physical characteristics of the house have changed considerably, while living habits and lifestyles have not changed at the same pace, thus the habitats should be physically harmonious with traditions and lifestyles with privacy, and available at moderate cost; otherwise, residents would react and try to change the environment according to their wishes.

As a consequence of three decades of war and conflict, more than half of urban houses have been destroyed and the same proportion of rural houses has also been devastated. According to this estimate, about one million houses were destroyed either by direct impact of war or by erosion all over the country. Moreover, during the last twenty years, some 10,000 new housing requests have been exceeded annually; with $5 \%$ population growth rate this amounts already to 200,000 new houses. [1] - [5]

Substantially, provision of 1,200,000 new houses, primarily in Kabul, is a great social problem and a heavy burden upon the national economy. Furthermore the informal settlements developed without planning and with the bare minimum of infrastructure and facilities, constitute a great impediment towards developing housing.

According to the recent, thirty-year Master Plan of Kabul city (1971-1975), 80\% of the existing housing of the city had to be destroyed in order to build apartment blocks of 4-12 stories instead. Building of high-rise, monotonous apartment dwellings has not only been a substitute for the native, traditional and Islamic architectural style, but significant land topography has also been ignored. The Master Plan has been deemed impractical, because it could not draw the attention of the people, and it was beyond the scope of either the public or private sectors. Moreover applying industrial materials and construction and relying mostly on imported building materials - i.e., cement and steel - unsuited to the domestic climate were among the considerations of the Master Plan. [5] The housing sector, unlike the past in which a few projects sufficed, has to hold an appropriate position in the micro-developing plan of the country. The contribution of the housing sector has to be more than the $5 \%$ of the past. Besides, establishing a bank for housing development will create the opportunity to order the investment market and direct random and underutilized investment toward the housing sector, with the possibility of joining the investor, bank and consumer together. This step can thus also be conceptualized as a combination of these four significant aspects. (Figure 1)

Moreover, it supplies aspects of policy-making and sanction for many executive programs such as land provision, offering infrastructure, granting loans and subsidies for building housing and for tenement housing to be gradually owed and delivered to qualified and vulnerable social groups, including low- and middle-income groups, the handicapped, and non-caretaker families. Besides, the authorities would be able to control and assemble the market for building materials as well. The basic model for sustainable-affordable housing proposed in this research also adopts this principle-based approach based on our definition of sustainable-affordable housing for poor and low-income citizens. Sustainable-affordable housing development has four major factors, as we will discuss later, namely, socio-cultural, economic, technological and environmental sustainability. Urbanization and sustainable and affordable housing policy is taking place in Afghanistan at a fast pace, but little information is available on the subject. This to some extent has been due to the fact that urbanization has been a rather new phenomenon in the country, and has thus received low priority in the governmental hierarchy of development programs. Furthermore the absence of reliable statistics has limited any systematic study of the subject. There are only a small number of scattered documents and papers about the subject, because urbanization and technological change have been rather new processes in Afghanistan. Recent forces of modernization, mainly during the past three and a half decades, may have brought new opportunities in major cities, but at the same time they have created new imbalances.

One main issue for the housing sector, the lack of institutional finance, remains a major constraint to the development of a housing market in Afghanistan. The government-owned housing finance bank was closed in mid-2003 because of poor performance. The sixteen commercial banks operating in the country today, while perceiving the housing finance market in the main cities as potentially lucrative, have extended little financing to the housing sector.

While the availability of long-term funding remains a challenge, the problem is largely not a financing issue: the banks have excess liquidity. The problem is instead an inefficient financial intermediary function for generating long-term funds, and the lack of a legal regime that supports long-term loans, such as those for housing. The consequence is that houses are purchased on a cash basis, precluding all but the wealthy from participating in the market. A housing finance system could provide benefits to the economy beyond development of a housing market. For example, instituting a sound property registration system would enable entrepreneurs to use their 
property as collateral for business loans. In addition, housing finance would help develop a long-term finance market for other industries, including infrastructure development. In addition, private sector lending for housing would free scarce government resources for other social and economic needs. [66]

The main factor behind the growing housing crisis in Afghanistan, especially in the capital city of Kabul, is the lack of regulations, Design and national housing policy from the government sector concerns the application of sustainable methods. The lack of regulations is evident in the fact that there are no enforceable building codes, nor is there any regulations to follow that integrate the principles of sustainable architecture in the country. Several researchers have argued that one of the most significant and cost-effective ways to foster the prevalent use of sustainable practices is setting a comprehensible set of codes, standards and policy, specifically with regard to diminishing household energy and water consumption. These regulations will need to follow the laws of Islam and incorporate the conservative Islamic culture and Afghan culture (Afghan walai) of Afghan residents. Afghanistan is a conservative Muslim country where the jurisdictional base of any act should be based on what is transcribed in the Holy Quran and the Sunnah (the sayings and deeds of the prophet Mohammed). In addition, to understand the economic system of Afghanistan, one must comprehend that the economic system is based on the Quran and Sunnah, the accumulated knowledge of Islamic jurisprudence generated by consensus (Ijma), analogy (Qiyas) and independent interpretation (Ijtihad). Understanding the Islamic Economy principles is crucial for creating an Islam-based housing finance, which is the case in Afghanistan.

\section{Literature Review and Conceptual Framework}

Sustainable affordable Housing: The housing must be market-competitive quality that can blend into its neighborhood. Thus we are explicitly excluding substandard locations, configurations, constructions, and maintenance. Such 'structures,' to use the Kenyan euphemism, may be 'shelter' but are not housing.

Affordable: The housing must be affordable for its target market; this means what the householder pays. Affordability must also continue throughout the expected life of the tenancy.

Housing quality and housing affordability must continue over the housing's expected useful life (typically 30-50+ years). This implies that the housing must take in enough cash flow to cover its expenditures, including capital expenditures [16], [20], [26]. Affordable housing is provided at below market prices, for people with a local connection to Kabul, and for people who are unable to afford to purchase or rent houses generally available on the open market without financial assistance, as their only home.

\subsection{Housing Policy}

House building, forming the basic unit of human settlement in the built environment, is also a crucial component of social development. It plays an important role in achieving sustainable development. Social and cultural factors determine the primary requirements of housing. Financial capacity or affordability to an individual has the immediate effect of transforming this need or requirement into a sound reality. Technology acts as a catalyst to help in realizing this by providing affordable options suiting individual requirements and changing circumstances, along with accomplishing present demands. The needs and wishes of future generations should also be taken into account. The importance of sustainability of housing comes within this context. It embraces four, closely inter-dependent aspects: socio-cultural considerations, economy, technology and the environment (Figure 1).

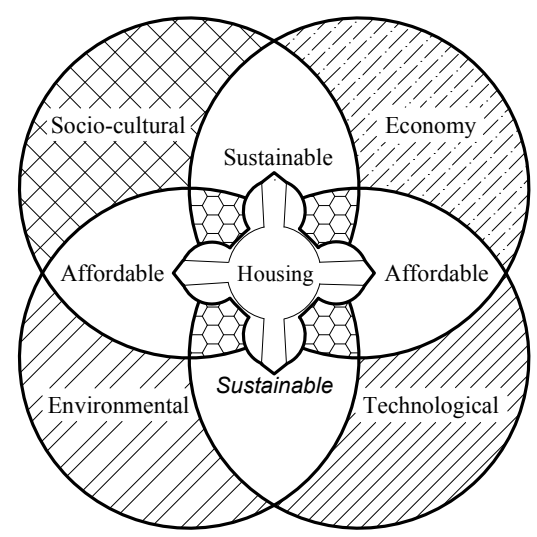

Figure 1.Basic concept for sustainable-affordable housing

A housing policy provides a guide, which delimits action and sets goals but does not necessarily specify any 
defined strategies for achieving the goal other than broad strategies. It establishes guidelines and limits for discretionary actions by individuals responsible for implementing the overall plan of action [55], [53]. Duruzoechi (1999) noted that some housing policy decisions (written or implied) express the overall past work of government, while others are goal statements or prescriptions of elemental rules for the conduct of personal or organizational affairs. Policies are thus well reasoned, carefully articulated and presented documents. (Olatubara, 2002). Housing policy is essentially necessary as a guide or control on the various actors in the housing sector. The main objectives of housing policy, according to Duruzoechi (1999), are to obtain the optimum use of existing housing resources in other to ensure adequate housing for the people, guide the location of new housing, and be responsive to the housing needs of special people.

What is the aim of national housing policy? The purpose of a national sustainable housing strategy should be creation of an integrated policy framework to guide the country in the development of a sustainable housing sector, while also assisting with the wider ambitions for poverty reduction, socio- economic development, and dealing with climate change. The strategy needs to integrate housing programs that already exist in the country with a broader framework aimed at creating a more sustainable and affordable housing sector. The national sustainable housing strategy should: (1) set out a clear housing vision for the country over a 10-20 year timeframe and key strategic objectives; (2) be based on a sound evidence base; (3) set out policies and a detailed action plan to implement the vision and objectives, giving details such as when, how, where and by whom actions will be delivered; (4) set out the outcomes expected from the delivery of the actions and the indicators that will be used to monitor progress towards them, including quantified targets; and (5) be reasonably concise and accessible to the general public (UN-Habitat, Sustainable Housing)

\subsection{Sustainability and Sustainable Housing}

There are many definitions of sustainability, but a well-known and accepted definition is the one proposed by the World Commission on Environment and Development in their 1987 study commonly known as the Brundtland Commission Report [37], [38], [41]. Sustainable development means "meeting the needs of the present without compromising the ability of future generations to meet their own needs." The term sustainability has become one of the most overused and all-too-frequently misused terms in the development literature [39], [43]. Choguill argues that we talk loosely about sustainable cities, sustainable housing and many other sustainable activities. Sustainable development has become firmly established in the community development and planning literature (Jepson, 2007). However, when it comes to practicing sustainable development, it remains largely outside the mainstream. Initially the concept of sustainable development was related to macroeconomic development and more recently it has been applied in human development, by implication housing (Choguill 2007). In economics, the capital approach is usually used to measure the sustainability of a development. This approach considers ecological and sociological aspects along with economic aspects. Uwasu and Yabar (2010) argue that the capital approach in economics is used as a sustainability measurement. He says that "as long as we are able to maintain or increase wealth (i.e., capital stock) over time, the goods and services necessary to fulfill human needs will be secured ${ }^{\text {te }}$ [46]. The concept of sustainability started from human settlement, and from there it has gone further to address issues of housing and neighborhood development. Sustainable housing means "housing which contributes to community building, to social justice and to economic viability at a local level"e (Morgan and Talbot, 2001, p. 321). Sustainability should be the main principle to design housing and one of the important dimensions of housing quality (Morgan and Talbot 2001). Development of sustainable housing refers to not only the development of buildings. but also the layout of housing areas, as housing is a verb not a noun. (Turner 1976) Quality of dwelling life is not 'therefore, simply concerned with having a roof over one's head and a sufficient amount of living space, but also with social and psychological satisfaction. Sustainable physical design can contribute to quality of life"e. Hasic says that the social and behavioral elements of housing design are the key to the success of the residential development. Therefore social capital (the advantages that accrue from a social network) is a key component of housing sustainability and this could be achieved by encouraging the community's joint activities and social inclusion. "Social capital is not what you know, it's who you know." This quote sums up the general understanding of social capital. The concept of urban development and social sustainability is also connected with the understanding of social equity, social inclusion and social capital (Bramely and Power 2009). Therefore, to develop sustainable housing, housing initiatives must be socially acceptable, economically viable, environmentally friendly and technically feasible (Choguill, 1999). In theories of sustainable development, usually these three aspects are treated as separate but interrelated entities (Giddings et al. 2002). The theories behind sustainable development are shaped by people and organizations' different worldviews, which influence the formulation of the issues and actions proposed. Theories of sustainable development stress the need to take a "whole systems" approach that appreciates emergent properties, complexity and intersections (Giddings et al 2002, p.187). The social capital 
approach could support the achievement of sustainable affordable housing because social capital could facilitate access to a range of other capitals, including economic and cultural capital, which in turn determine an individual's position within the social structure (Bourdieu 1986).

\subsection{Affordable Housing}

What is affordable housing? Affordable housing is generally considered to be housing that meets the needs of households whose incomes are not sufficient to allow them to access appropriate housing in the market without assistance. Unfortunately, like sustainability, housing affordability is also overused and misused. Hulchanski $(1995$, p.1) argues that in recent years, "housing affordability" has become a commonly used term for summarizing the nature of the housing difficulty in many nations. He identifies six elements of measuring housing expenditure to an income ratio to measure housing affordability. These six elements are developed based on North American usages. The six elements are: "(1) description of household expenditures, (2) analysis of trends, (3) administration of public housing by defining eligibility criteria and subsidy levels, (4) definition of housing need for public policy purposes, (5) prediction of the ability of a household to pay the rent or the mortgage, and (6) as part of the selection criteria in the decision to rent or provide a mortgage. Each of the six uses is assessed based on the extent to which it is a valid and reliable measure of what it purports to measure." (Hulchanski, 1995, p. 1) He says the term "housing affordability" is misleading, and we should not use it because household consumption patterns and the means by which households meet their needs are very diverse. It is easy to grasp the concept of affordability intellectually, but it might be hard to pin down in practice, because of the changing circumstances of families and individuals (Paris 2007). Again, measurement of affordability varies from place to place and country to country, but the most accepted measurement of affordability is the ratio between household income and housing cost (Hulchanski, 1995). A well-known and well-practiced measurement of affordable housing is that housing cost should be less than $30 \%$ of household income of the occupants in the bottom $40 \%$ of household incomes [16], [23], [25]-[32].

The issue of housing affordability is multi-dimensional. Numerous studies have identified many factors associated with housing affordability, such as interest rates, income levels, construction cost, land supply, and housing prices. The problems are many and they are all interwoven. One of the biggest problems low-income households face today is finding affordable and appropriate housing. Affordable housing refers to housing that is affordable to lower- or middle-income households. It includes owner-occupied housing as well as rental housing owned by government, nonprofit organizations, corporations or individuals [27], [34], [37].

Many researchers have undertaken numerous studies on affordable housing across the world (Berry, 2006; Burke et al., 2007; Wendell, 2005; Yates and Gabriel, 2006; Yates et al., 2008; Yates et al., 2007; Lloyd-Sherlock, 2000; Whitehead, 2006). These studies generally address one of the housing affordability issues, such as fiscal implications, housing finance, problems of housing affordability, which has an affordability problem, policy, planning etc. However, there is not much research on an integrated approach to address issues of housing affordability. Again there is literature on housing affordability and housing sustainability, but not an integrated approach to housing affordability and sustainability.

As mentioned, sustainable-affordable housing not only helps to create a social balance, but it is also helpful for economic development. The points below show the effects of affordable housing on economic development of communities. Affordable housing contributes to economic development through its capacities to:

- Stimulate economic growth through housing markets and homebuilding activities;

- Stabilize and reduce volatility of housing markets;

- Improve health conditions and labour productivity through better living conditions;

- Add to the growth of capital assets of the gross capital stock;

- Support regional and urban regeneration, development and growth;

- Contribute revenues to local, regional and national governments (e.g. via taxes) and individual wealth (e.g. via housing markets);

- Generate employment and income through residential and building activities and their multiplier effects in other sectors;

- Strengthen local building industry and enterprise and promote local and traditional building materials and techniques;

- Provide domestic financial mobilization through housing finance institutions; 
- Generate additional income by raising collateral for business start-ups and small firm growth, as well as through home-based enterprises and renting. (UN-Habitat, Sustainable Housing)

The next section will investigate the relationship between sustainable residential development and affordable housing.

\subsection{Sustainable Development and Affordable Housing}

Housing means a roof over the head, whereas sustainability and housing is more than a roof over the head [38] Affordable housing also limits the cost of housing because households should not pay more than $30 \%$ of their household income. This aligns with the aim of the capital approach, where social and ecological outcomes are trade-offs with economic thresholds. Therefore, it is a real challenge for both facilitator and provider to provide affordable housing, which is also sustainable. As we know, sustainability does not only mean economically viable, but also socially and environmentally sustainable. Therefore, there is a need to trade off between various sustainable elements to achieve sustainable housing that is affordable. Unfortunately, currently the sustainability of housing is very much related to economics, and to some extent the environment. However, to improve the quality of life, social sustainability plays a vital role.

Sustainable development is often defined as development that meets the needs of the present without compromising the ability of future generations to meet their needs (World Commission for Environment and Development, 1987:23). 'Meeting the needs of the present' refers to the development aspects of sustainability, which includes economic, social, cultural and political issues. The second phrase of the definition 'without compromising the needs of the future' mostly refers to environmental issues (Ebsen. C and Ramboll.B, 2000). Human settlements should be planned, developed and improved in a manner that takes full account of sustainable development principles. Sustainable-affordable habitat could be described as a way of developing and maintaining the living environment that supports human health (both physical and psychological), satisfying their shelter needs, along with protecting and preserving nature for future generations. The conceptual framework for sustainable-affordable habitat has been formulated to achieve housing development by balancing social progress, enhancing economic growth, propagating innovative technology, along with conserving and protecting the environment and natural resources for future life and development.

The following are the main contribution of planning to sustainable-affordable housing:

- Limit urban sprawl and car-dependency by ensuring appropriate levels of building density and mixed-use developments, organizing transport flows, public transport and non-motorized transportation options;

- Deliver comprehensive programs for rehabilitation and regeneration of slums and other problematic areas (e.g. derelict, former industrial) and ensure better living and environmental standards in the built environment;

- Bring together disparate residential developments of the city to ensure integrated residential patterns (e.g. re-designing and upgrading slums as the city's neighborhoods);

- Ensure social inclusion and socio-spatial integration, by preventing social segregation and mitigating social imbalances between neighborhoods;

- Transform existing low-density areas towards mixed-use development, based on a strategy of stimulating polycentricism;

- Ensure the provision of social infrastructure and amenities and accommodating the particular needs of various social groups through appropriate spatial organization, densities and design;

- Preserve and expand an integrated system of green spaces and other natural infrastructure;

- Protect cultural and architectural heritage of urban areas and integrate them into the urban tissue;

- Increase recycling infrastructure in the city, install waste-to-energy technologies; promote sustainable material cycles via design control;

- Develop integrated infrastructure for renewable sources of energy, district heating-cooling-electricity systems and waste-to-energy. (UN-Habitat, Sustainable Housing For Sustainable Cities)

\subsection{Goal for Sustainable-Affordable Housing}

Sustainable-affordable housing embraces the four objectives of sustainability, namely, socio-cultural, economic, technological, and environmental goals. Since housing is a primary component of habitat, sustainable housing 
development activities can directly contribute to the development of sustainable habitat. Sustainable habitat can be achieved through promoting housing development by balancing social progress, enhancing economic growth, propagating innovative technology, along with conserving and protecting the environment and natural resources for future life and development[18]-[23]. A list of criteria has been prepared to measure these objectives and assess the present housing situation based on the concepts of sustainable-affordable housing. The ensuing text explains these objectives on the basis of different criteria. It defines and structures fundamental values under each aspect of sustainability, and further guides planners toward integrated decision making (Figure 2).

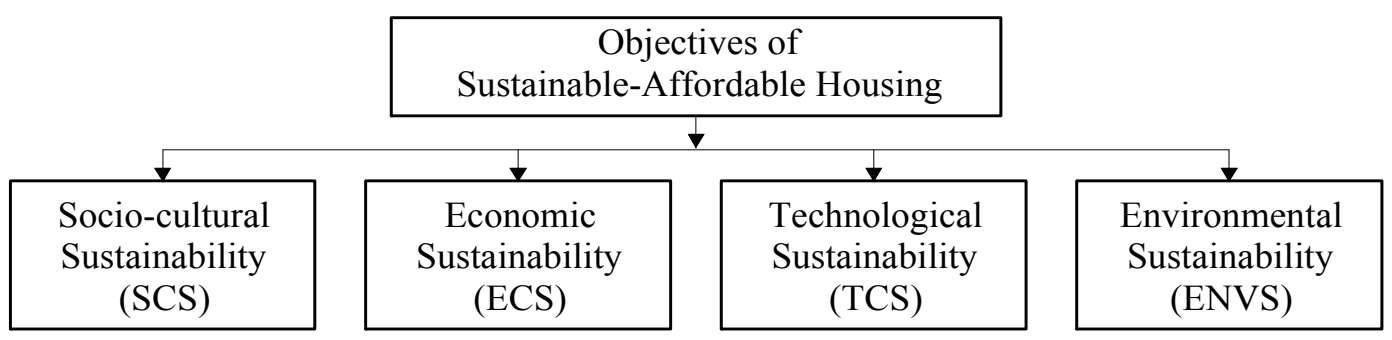

Figure 2. Objectives of sustainable-affordable housing in Kabul city

\subsection{Socio-Cultural Sustainability}

Affordable housing that is more economically sustainable also helps to create a more socially sustainable environment. For example, a family of recent immigrants into the Unites States would value a building much more if they had the power to adapt certain design aspects to fit their cultural practices. In affordable housing, this gives a sense of psychological ownership of space to people who may have never had that before. The concept of shelter differs from individual to individual depending on culture, tradition, profession and way of living. The design and materials used for the house should correspond to the user's way of living and local building traditions (Christel Ebsen and Bjarke Ramboll, 2000). In most communities, houses are treated as part of the identity of the individuals labeling their status. People do not want to live in a house, which stigmatizes them as belonging to a low-income class, even if it is all that is affordable to them. The location and type of houses often reflect social inequalities. This also affects their social relationships, day-to-day living and ultimately the prospects of future generations. Besides being a basic necessity, it is also a source of identity that has a significant effect on the overall psychological well being of the inhabitants. It acts as a matrix that strengthens family and community ties. Different groups of people within the society should be able to participate equally. Socio-cultural sustainability in housing involves several dimensions, such as adaptability, equality, integration of amenities and services; self-help housing or beneficiary participation and community involvement. Sustainable housing should respond to the socio-cultural needs and practices of the beneficiary households and communities. It is focused on housing development that promotes social interaction of individuals and cultural enrichment of the community and is aimed to reduce the inequality of housing between social classes (Islam. N, 1996). At the same time, it accelerates the improvement in social development, relations and interactions.

The various criteria for defining socio-cultural sustainability in housing have been identified as adaptability, equality, integration of amenities and services; self-help housing, or beneficiary participation and community involvement. Adequate shelter is not only a human right, but also a basis for human dignity and relationships. Sustainable housing should respond to the socio-cultural needs and practices of the beneficiary households and communities. It is focused on housing development that promotes the social interaction of individuals and cultural enrichment of the community, and aims to reduce the inequality of housing between social classes (Islam, 1996). At the same time it accelerates the improvement in social developments, relations and interactions.[21]-[28] [Muhammad - Here you repeat verbatim some sentences from the previous paragraph.]

The concept of shelter differs from individual to individual, depending on culture, tradition, profession and way of living. The design and materials used for the house should correspond to the user's way of living and local building traditions (Christel Ebsen and Bjarke Ramboll, 2000). In most communities, houses are treated as part of the identity of individuals, labeling their status. People do not want to live in a house that stigmatizes them as belonging to a low-income class, even if it is all that is affordable to them. The location and type of houses often reflect social inequalities. This also affects their social relationships, day-to-day living, and ultimately the prospects of future generations. Besides being a basic necessity, it is also a source of identity that has a significant 
effect on the overall psychological well being of the inhabitants. It acts as a matrix that strengthens family and community ties. Different groups of people within the society should be able to participate equally. [Again, here you repeat several sentences from the paragraph before the previous one - is this your intention?] Socio-cultural sustainability in housing involves several dimensions, such as adaptability, equality, integration of amenities and services; self-help housing, or beneficiary participation and community involvement (Figure 3).

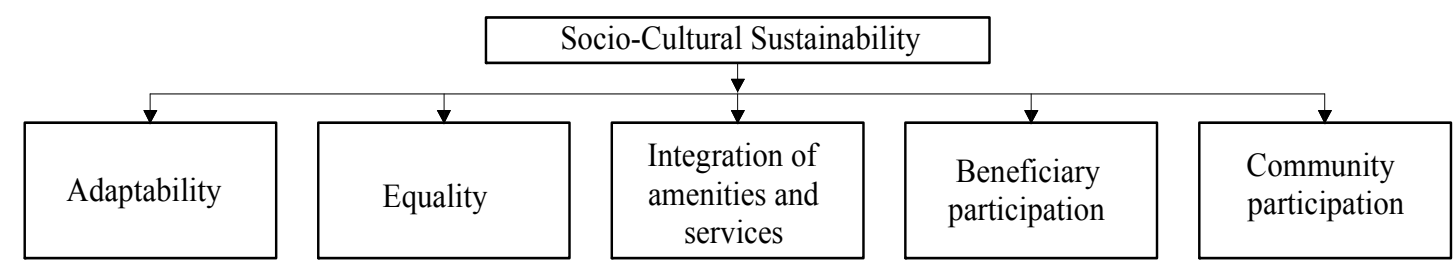

Figure 3. Socio-cultural Sustainability

1) Adaptability: The concept of shelter is much broader than mere housing. It differs from individual to individual depending on household size, culture, tradition, profession and way of living. The house design should be flexible enough to incorporate the changing needs of the individuals (family size, profession etc.). The provisions for future expansions or the flexibility to changing needs is an essential criterion. For instance the housing requirements change when children are born, or grow up, or marry, get children themselves, and so on. The flexibility to fulfill these varying needs is defined as adaptability in housing.

2) Equality: This objective has to be considered with utmost care, as it forms the basis for socio-cultural sustainability. Equality in housing development refers to the principle that segregation or grouping of a particular group of people based on income, religion or any other criteria should not be reflected in their housing and should not prevent them from participating in social activities. Different groups of people within the society should be able to participate equally.

3) Integration of amenities and services: Sustainable shelter requires the integration of essential culture or local specific amenities (privacy, security, lighting etc.) and public infrastructure facilities. It also refers to location, making the journey to work feasible. At the community level, social amenities like schools, libraries, recreation centers, medical facilities, police stations need to be integrated into settlements. [44], [53]

4) Self-help housing and beneficiary participation: Sustainable housing development can be perceived as a means to improve the livelihood and independence of the inhabitants. The users build houses to suit their needs and hence self-help or a participatory approach in housing brings desirable changes that lead to sustainable housing. Turner's three laws on housing are important in this context [27], [41]

5) Community Participation: Ensuring community participation is an important aspect of sustainable housing. For the lower- and middle-income population, communal action, whether in the political, social or economic realm, permits a scale of activity impossible as individuals (Jenkins, 1999). Community development is a key to unlocking higher levels of mutual advantage, as well as more effectively and equitably accessing state and economic resources. Successful community involvement requires support from the public sector through training, empowerment, financial assistance and guidance. Community participation is also necessary to develop housing clusters to create sustainable residential neighborhoods. The possibilities are greatly multiplied when governments actively try to foster development simply by bringing people into the process.[25]-[32]

One of the major social challenges in contemporary sustainable housing in Afghanistan is achieving privacy. Privacy is crucial in the design of a Afghan house, and the concept of privacy is perceived from three different areas, as stated between the neighbor's dwelling as well as the street, gender and privacy between individual family members "The concept of privacy has become a subject of growing concern for people, architects, urban designers, landscape architects and social scientists involved in development projects in Afghanistan. [67]-[72]

\subsection{Economic Sustainability or Affordability}

Economic growth is the key to provide the means to meet basic needs, to reduce poverty and to generate employment, factors that are essential for sustainable development (Veron, R 2001). Even though housing problems arise as a symbol of poverty, mere financial assistance usually does not help the poor in meeting their housing needs. Economic sustainability or affordability in housing should be embedded in an economic development strategy, which strengthens the economic self-reliance of household members. Even though the 
housing problem arises as a symbol of poverty, mere financial assistance usually does not help the poor in providing housing. Affordability by a household in any part of the world depends on its command over the various resources required for housing. The poor often cannot afford to accept public housing assistance due to the lack of economic sustainability or affordability of the housing programs. Affordability by the households, their basic shelter needs, and their pre-requisites or resources for housing development have been identified as the essential criteria for measuring the economic sustainability of housing (Fig .4). As improvement and development of society are closely related to economic development, socio-cultural sustainability is closely linked to economic sustainability. The affordability of a household in any part of the world depends on its command over the various resources required for housing. The command over these resources must be given right priority while planning for any housing development program. The most important financial resources are the actual and potential savings of the inhabitants. This probably represents between 10 to $15 \%$ of all personal incomes (Turner, J, F, C 1976). Housing programs may be linked to programs generating employment, or income enabling the poor to afford their own houses and maintain them (Bhattacharya, K, P 1994). The housing sector is employment intensive; it generates employment during the construction period and also during its life for proper maintenance providing employment opportunities for skilled as well as unskilled labor (Glaeser, B 1995 and Tiwari, P 2001). Economic sustainability or affordability of housing should be embedded in an economic development strategy, which strengthens the economic self-reliance of household members. The poor often cannot afford to accept public housing assistance due to the lack of economic sustainability or affordability of the schemes.

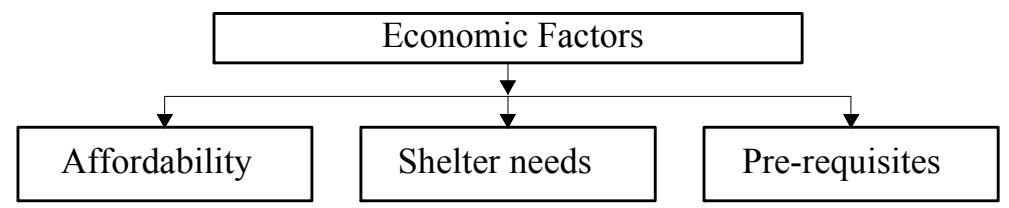

Figure 4. Economic Sustainability or Affordability

1) Affordability: Affordability by the households must be given right priority before planning any housing development program. The most important financial resources are the actual and potential savings by the inhabitants out of their income. This probably represents between 10 to $15 \%$ of all personal income (Turner, 1976).

2) Pre-requisites: Access to land, resources and basic infrastructure is a pre-condition for affordable housing (Bhattacharya, 1994). Houses cannot be built and managed or maintained without resources, infrastructure and land to build on. [34], [38]

3) Shelter needs: Affordable housing can said to be sustainable only if it provides basic facilities and amenities essential for the wellbeing of the inhabitants. According to UNCHS (1990), country-specific modes of adequate shelter are suggested as sustainable solutions since they are environmentally appropriate, economically attainable and therefore realistic. For instance, an affordable type design of a house with minimum essential facilities may sometimes be unrealistic, if it cannot fulfill the basic housing needs of the household members.

Economic growth is a key in providing the means to meet basic needs, to ease poverty, and to generate employment, the factors essential for sustainable development [33]. Housing activity is closely linked to the macro-economy. It is capable of producing employment and growth. Investments in this sector not only improve and add to the existing stock of housing units, but also improve the working and living conditions. The housing sector is employment-intensive. It generates employment during the construction period and also during its life for proper maintenance, providing employment opportunities for skilled as well as unskilled labor [37], [51], [58]. [67]-[72]

\subsection{Technological Sustainability}

Technology can be said to be sustainable only if, it takes advantage of local resources and can be produced locally using unskilled labor, utilizing already available materials without the need for heavy capital investment. It should benefit as many people as possible and should be flexible and functional also, i.e. adaptable to the changing needs of the community; at the same time it should also be environmentally friendly. It must be affordable and workable at the community level. Feasibility, functionality, strength, durability and reliability are identified as the basic necessities for technological sustainability.

Conventional building materials are beyond the reach of the majority of the world population due to their poor affordability. Besides the escalation in the cost of building materials, rising environmental concerns due to the extensive exploitation of natural resources connected with general construction and other housing development 
activities urge the search for alternative technological options. It is now generally agreed that development in the low-income countries must proceed in parallel with a general global application of new technologies, which are both less resource intensive and less environmentally damaging [18]. In both these respects, technological sustainability is connected to economic and environmental aspects of sustainability. It is also related to socio-cultural sustainability, as technological innovations reflect social demands, and those are in general culturespecific. Sustainable construction can be described as a way of designing and constructing buildings that support human health (physical, psychological, and social), and which is in harmony with nature, both animate and inanimate [35], [43].

Feasibility, functionality, strength, durability, reliability and environmental friendliness are identified as the basic necessities for technological sustainability (Fig. 5). [67]-[72]

1) Feasibility and Functionality: The technological innovations should be feasible to the users. Technology that utilizes local resources, unskilled labor, locally available and renewable materials can be said to be sustainable. It should be able to benefit as many people as possible and should be flexible and also functional, adaptable to the changing needs of the community; at the same time it must be affordable and workable at the community level.

2) Strength: The techniques of construction and materials used should be strong enough to meet the basic strength parameters appropriate to the local circumstances.

3) Reliability and Durability: These are closely related to the strength parameters and figure essential criteria for long-term sustainability. Durability refers to the property of a material, building section, or construction that can resist any unacceptable deterioration of relevant functional characteristics through specific chemical, physical and mechanical loads over a certain period of time.

4) Environment friendliness: Environmental friendliness of technological options in sustainable constructions refers to the minimized usage of renewable and non-renewable resources, extensive utilization of waste materials, as well as minimizing the impact of waste products and pollution.

Alternative materials, methods and techniques of construction replacing conventional building construction can result in reducing the depletion of natural resources and save energy (Reddy, B, V, V and Jagadish, K, S 2001).

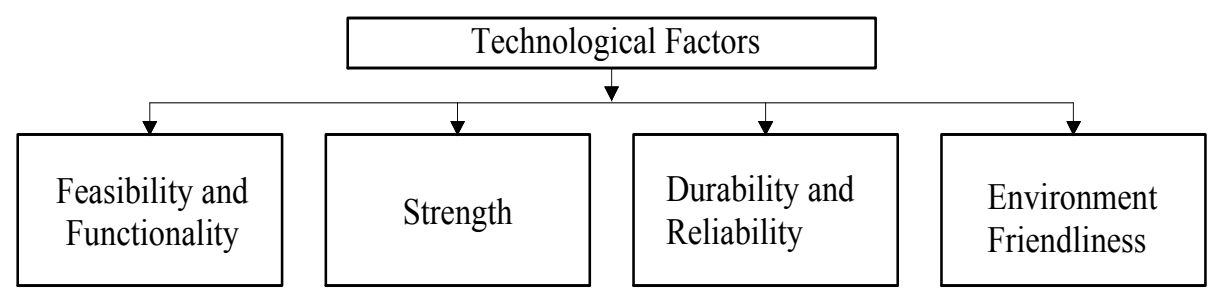

Figure 5. Technological sustainability

\subsection{Environmental Sustainability}

Environmental sustainability in housing can be achieved by addressing resource limits of the environment through efficient consumption of non-renewable resources, minimizing the impact of waste materials and pollution by utilizing appropriate technologies and making use of local work forces. Environmental sustainability requires the alleviation of poverty if it is to be meaningful. Many environmental problems often actually originate from lack of development and environmental degradation, in turn leading to poverty. Overall, the concept of sustainable development suggests a potentially positive relationship between socio-economic development and environmental sustainability (Veron, 2001). The positive environmental changes generate economic empowerment, enhance social capital and build institutional capacity. In order to be sustainable, developments in the economy and social changes should be able to sustain ecology and improve potential resources for future generations. We have entered an era in which no country is isolated and secure from the impacts of the environmental conditions of its neighbors. All countries have a stake in each other's present and future wellbeing. Environmental sustainability is the most significant concept of sustainability, as it takes care of the demands of present and future generations. [67]-[72]

According to the World Watch Institute, building construction consumes $40 \%$ of the raw stone, gravel and sand, $25 \%$ of the virgin wood, $40 \%$ of energy and $16 \%$ of water used annually worldwide [32]. The construction industry is involved in activities that adversely affect the environment through the over-exploitation of non- renewable resources. It may result in stripping of topsoil and destruction of natural topography, resulting in problems such as erosion, landslides, and detrimental effects upon local hydrology. This also contributes to the loss of fertile soil and 
to destruction of agricultural land, along with the depletion of natural resources and pollution of the environment by the emission of dust, debris and toxic gases as byproducts of the building process. Statistics of total energy consumption show that the proportion of energy consuming for building activities in the developing world is $35 \%$ of the total annual energy consumption. It utilizes energy for the development or production and transportation of materials and machinery, building, and also for maintenance activities. Efficient use of renewable and non-renewable resources, proper land management, provision of healthy surroundings, basic infrastructure facilities and waste management have been identified as the basic criteria for achieving environmental sustainability in housing .

1) Renewable and non-renewable resources: Minimizing or effectively utilizing the resources and promoting the usage of sustainable resources are the main concerns in this context. Especially energy and other non-renewable resources in household activities and the building process need specific attention. The overexploitation of natural resources should be restricted. The recycling or reuse of water, and rainwater-harvesting systems can be included as essential aspects along with basic infrastructure facilities.

2) Land conservation and proper planning: Modern housing development has a major impact on the environmental system. Damage to sensitive landscapes, including scenic, cultural, historical and architectural sites must also be given due consideration. The unrestricted and unplanned growth of housing development should be prevented. [67]-[72]

3) Healthy environment: The habitat as well as the nearby environment should be favorable to the healthy development of inhabitants, both physically and mentally.

Planning of both the indoor and outdoor environment need prime concern with respect to ventilation, thermal comfort and lighting through proper planning and orientation.

4) Infrastructure: Infrastructure can be divided into two components, social infrastructure and physical infrastructure. The social infrastructure refers to educational and health care facilities. The physical infrastructure includes water supply, sanitation, drainage, transportation, and solid waste management and land management. The provision of physical infrastructure must be seen as a prerequisite to achieve sustainable human settlements (Choguill, 1996). Infrastructure development is essential to improve the quality of life for human beings as well as the protection of the environment.

5) Waste management and material efficiency: The processes involved in the provision and use of housing have a significant role in the contribution of solid waste. Household activities also supplement the accumulation of waste, further polluting the environment. Construction and demolition debris accounts for about 15-30\% of solid waste by weight, representing a major component of all municipal solid waste (Kartam et al., 2004). Reducing material wastage has several benefits. It reduces global material consumption and, in the long term, also the amount of demolition waste. It also reduces construction costs, making houses more affordable. When properly done, recycling waste as building materials is a convenient way to reduce the environmental impact of the construction industry (CIB and UNEP, 2002).

Environmental sustainability of sustainable housing development should consider the following objectives as basic requirements for sustainable housing developments. It should be able to ensure (Fig. 6):

a) Basic infrastructure by provision of drinking water, drainage and sanitation, waste disposal, and electricity.

b) Energy efficiency by minimizing the use of non-renewable energy in daily household activities, utilizing alternative solutions for renewable energy.

c) Water efficiency by reuse of water, protecting water quality. Rainwater harvesting methods should be integrated with housing projects.

d) Land management by conservation of agricultural land. Proper regulatory measures should be taken against uncontrolled land reclamation for clay mining, housing and other development.

e) Indoor environment by improving air quality and improving thermal comfort.

f) Surrounding environment: Improving biodiversity.

g) Waste management: Proper disposal and recycling of household waste.

In order to be sustainable, developments in economy and social changes should be able to sustain ecology and improve potential resources for future generations. The construction industry is involved in activities that adversely affect the environment through the over exploitation of non-renewable resources. It utilizes energy for 
the development or production and transportation of materials and machinery, building and also for maintenance activities. According to the World watch Institute, building construction consumes $40 \%$ of raw stone, gravel and sand, $25 \%$ of virgin wood, $40 \%$ of energy and $16 \%$ of water used annually worldwide (Dimson.B, 1996). The processes involved in the provision and use of housing play a significant role in the contribution to solid waste. Household activities also supplement the accumulation of waste further polluting the environment. Reducing material wastage has several benefits. It reduces global material consumption and in the long term, also the amount of demolition waste. It also reduces construction costs, making houses more affordable. When properly done, recycling waste as building materials is a convenient way to reduce the environmental impact of the construction industry (Agenda 21 for Sustainable construction in developing countries) (Fig. 6). [67]-[72]

We can summarize all our above discussion about Housing and building actions toward sustainability.

- Encourage community and housing developments that are socially cohesive, reduce isolation, foster community spirit, and sharing of resources.

- $\quad$ Create compact and clustered residential development, including reduced minimum lot sizes.

- Ensure housing that is affordable to a variety of income groups within the same community.

- $\quad$ Encourage a diversity of occupants in terms of age, social, and cultural groups.

- Choose location of housing areas near employment centers.

- Encourage use of regenerative energy including solar-oriented housing and neighborhood design

- $\quad$ Ensure use of building materials with low "embodied energy" which are also chemical-free and toxin-free.

- Introduce ways of waste reduction and recycling of waste materials as well as of promoting recycling by residents.

- $\quad$ Formulate and use landscape design standards that minimize the use of pesticides and herbicides.

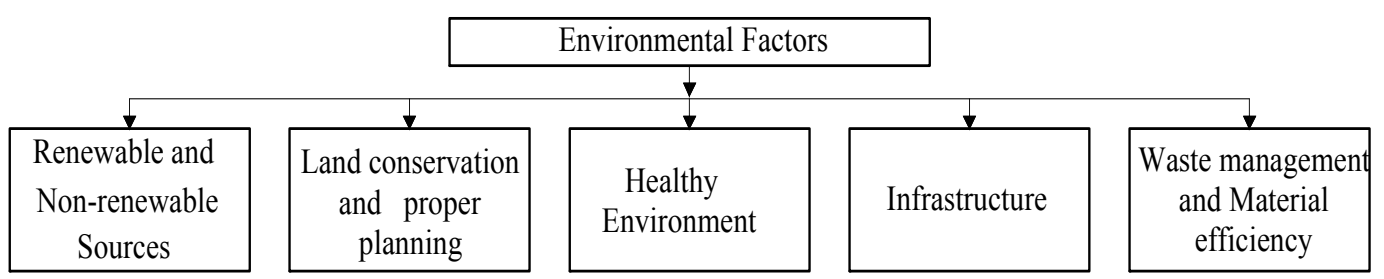

Figure 6. Environmental Sustainability

Based on the above discussion of different aspects of sustainable-affordable housing, the figure below presents an objectives hierarchy model for sustainable-affordable housing. This framework can be used for evaluating the present housing issues in Kabul or formulating guidelines for new housing projects for achieving sustainable housing development (Fig. 7). [67]-[72] 


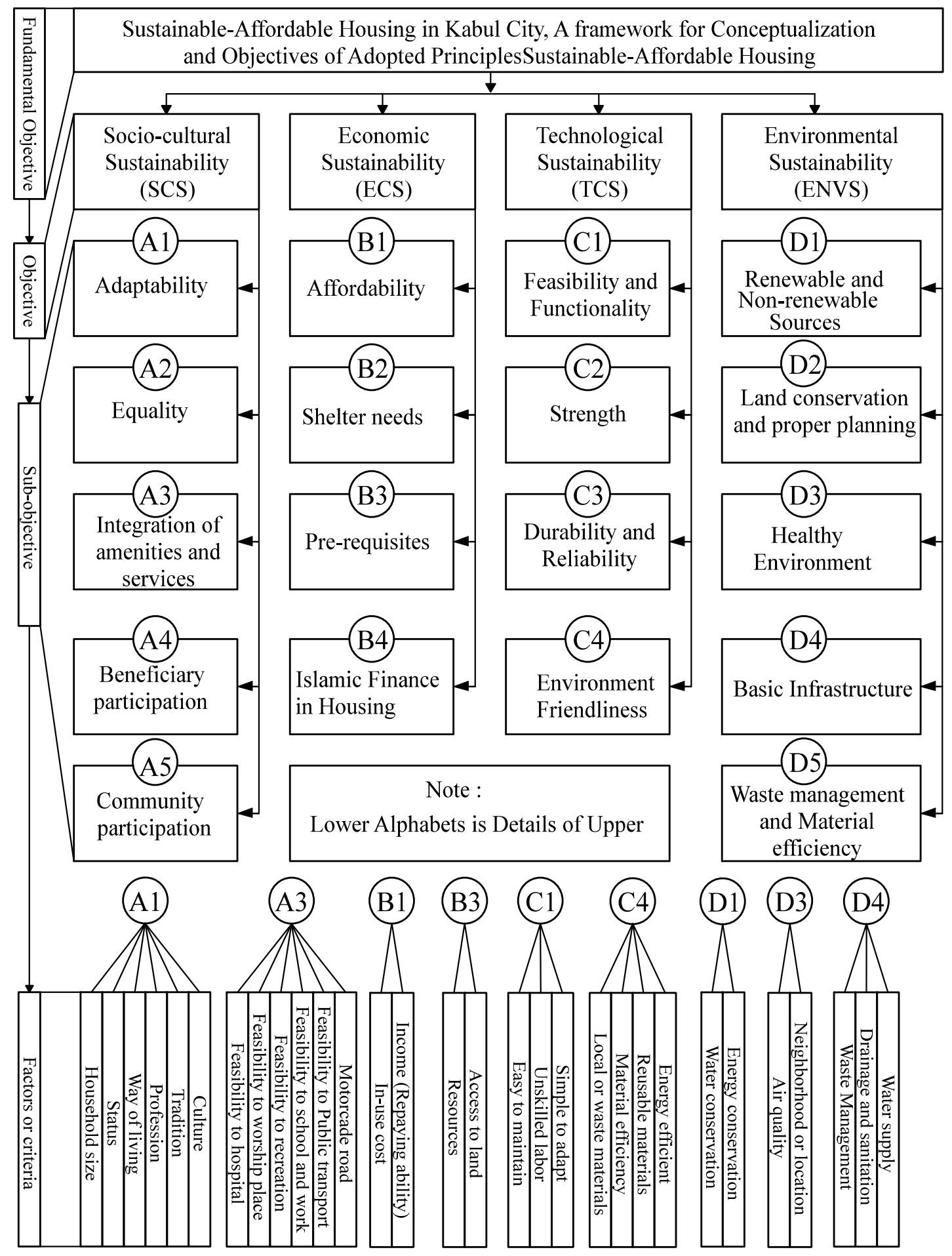

Figure 7. Sustainable affordable housing all frame work in Kabul city 
(SAH)

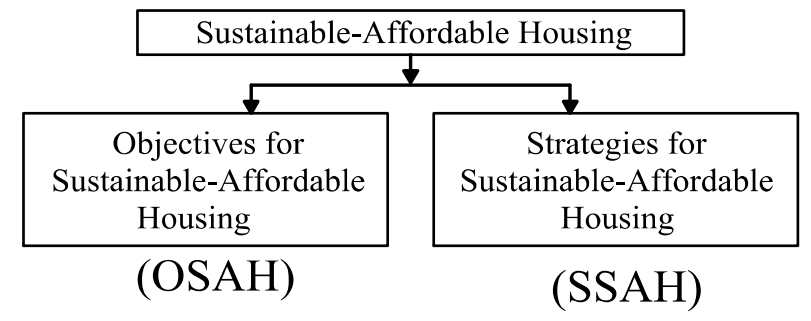

Figure 8. Sustainable-Affordable Housing Main Branch

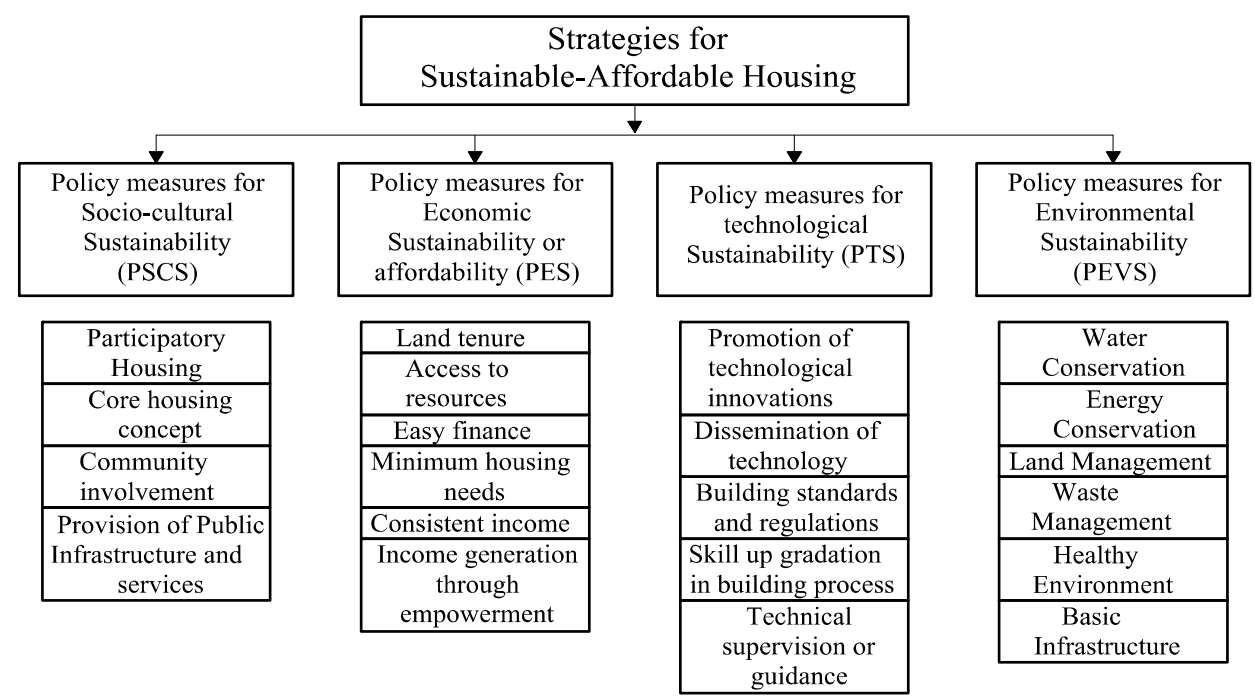

Figure 9. Sustainable-Affordable Housing Strategy elements Flow

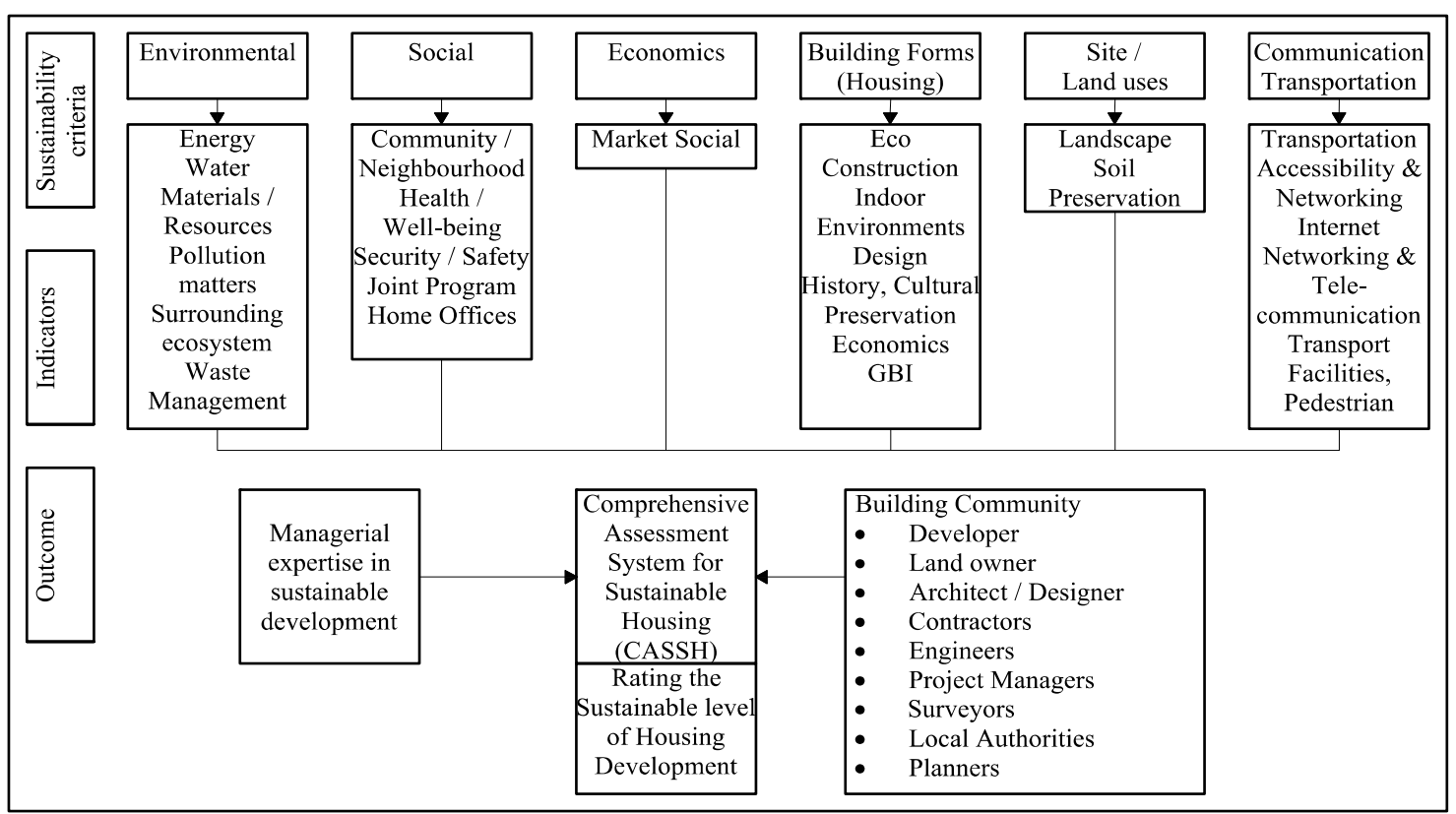

Figure 10. Conceptual frameworks for Comprehensive Assessment System for Sustainable Housing (CASSH ) in Kabul city 


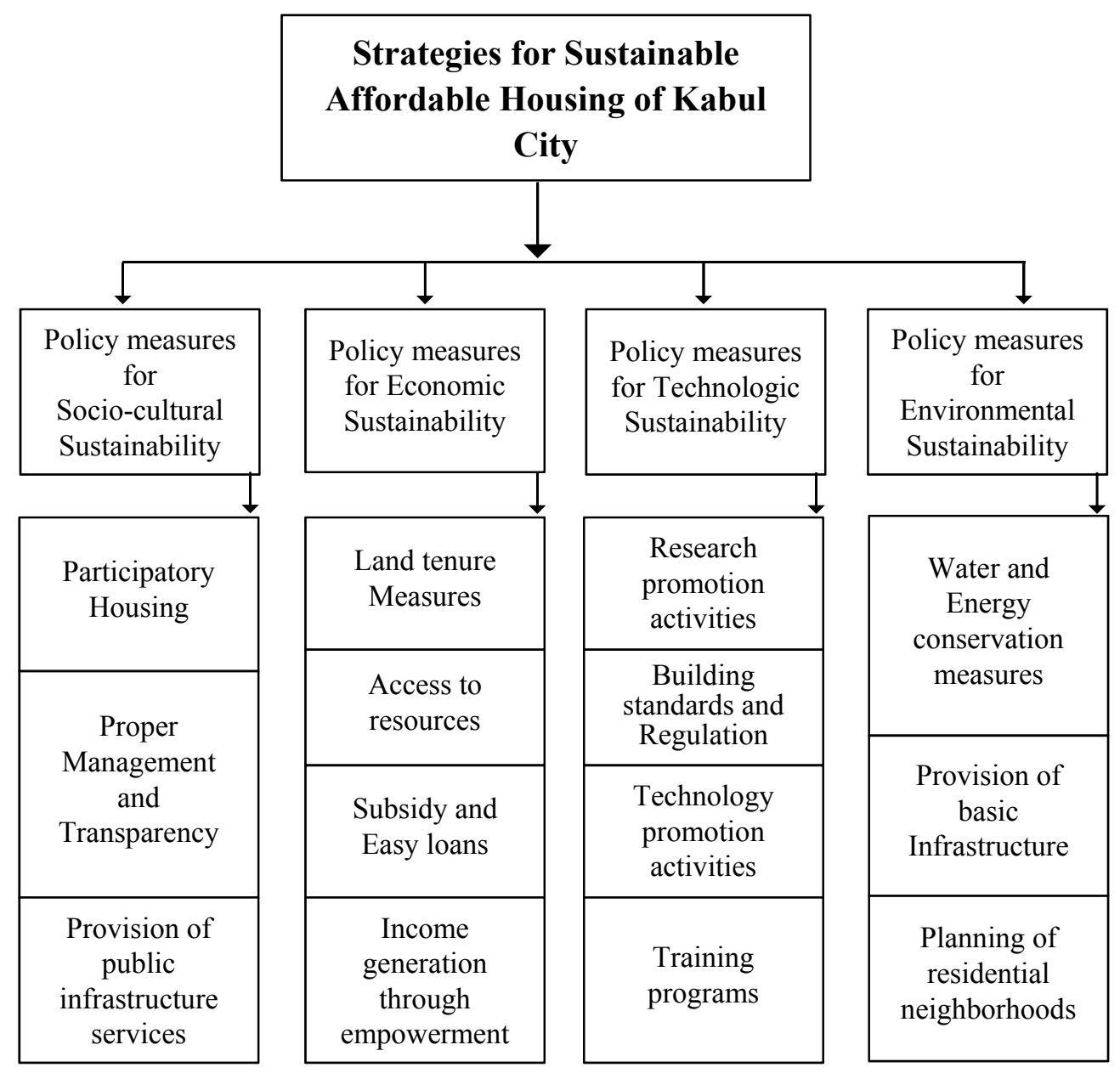

Figure 11. Strategies for sustainable affordable housing of Kabul city

\section{Objectives and Methods}

The research is qualitatively conducted in the form of policy introduction and adaptation. This policy research is a process of analyzing a fundamental, social and economic problem in order to provide policy makers with recommendations to alleviate the problem. This paper was developed in association with the Global Housing policy initiated by the Housing policy for Kabul, so affordable housing policy for Kabul is interrelated. Therefore, the aim of this study is particularly to come up with some policy recommendation on the provision of sustainable and affordable housing for residents of the Afghan capital. In particular, this research aims to examine the existing relationship between housing integration policies in Afghanistan, focusing mostly on low- and middle-income settlement in urban areas, which is not effectively applicable and usable.

A methodology based on the conceptual framework is employed in the analysis to understand the problem through a sustainability and affordability perspective, and to investigate the success and failure factors of public intervention in housing policy. The basic data set utilized in this paper was collected using applicable sustainable and affordable housing policy principles in development (developing OR developed) countries through governmental authorities or by some international association like the World Bank, UNCHS (on the evolution of present housing policy in developing countries) and (UN-Habitat). The second set of data is local site data, and a questionnaire administered to selected residents by house scale and neighborhood (Gawoond) scale.

This research has used a quantitative approach with emphasis on the importance of the research variables defined in terms of the operationalization of each of them. These variables are measured so that the data consists of numbers that can be analyzed by statistical procedures. Data collection techniques in this research are divided into two ways, the collection of secondary and primary data. Primary data was collected through questionnaires, field observation, and interviews. Secondary data was collected from the literature and data from several local and international sources. 


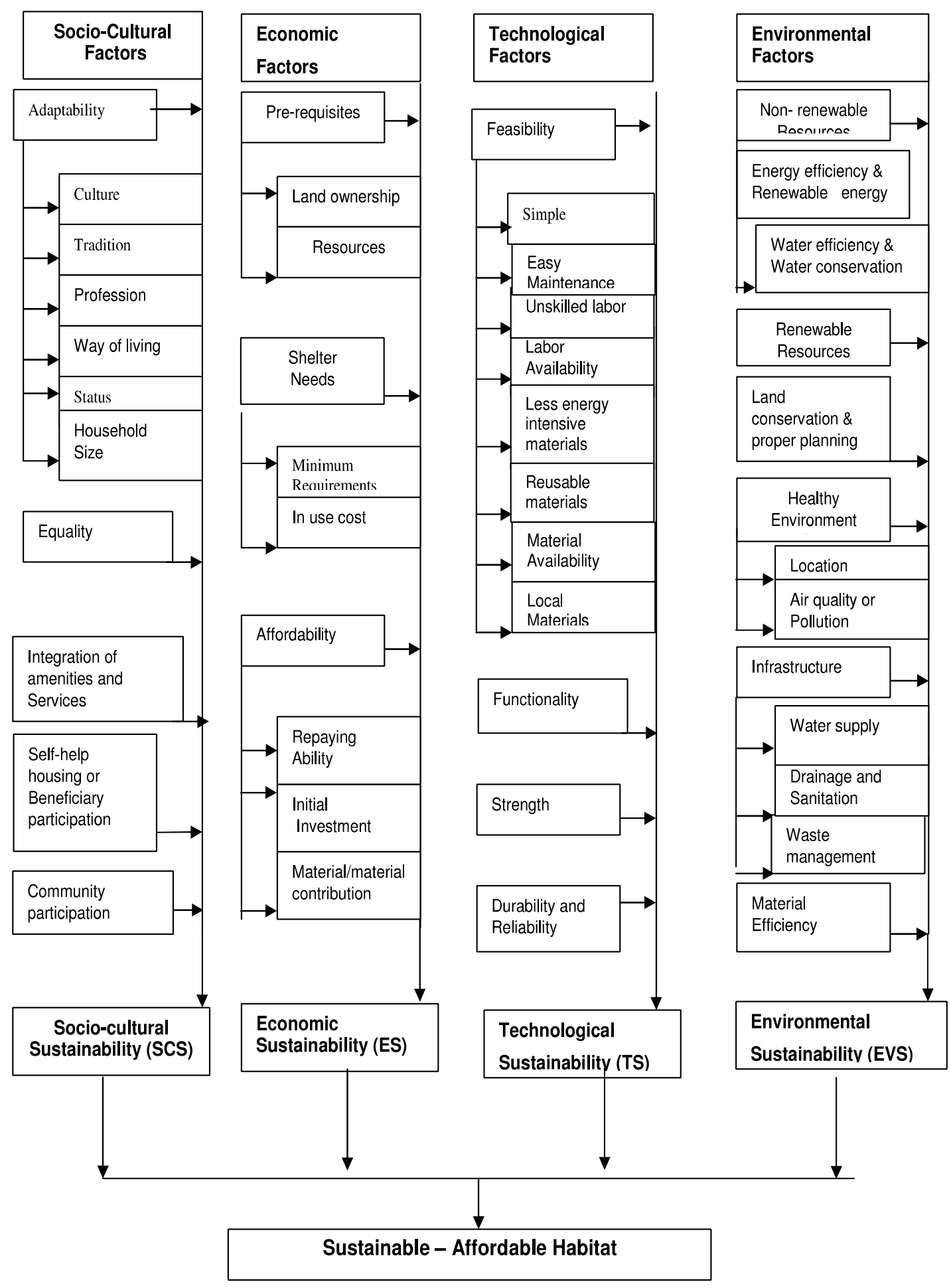

Figure 12. Sustainable and affordable habitat conceptual frame work

This research has adopted both a social science and technological approach in reaching different objectives and experimental technical research has been carried out in this article. Generally, the objective of this examination is to involve all main factors having connection with sustainable and affordable housing policy. The economic study on the household demand for sustainable housing in Kabul city to identify the availability and to determine the affordability of decent low-cost residential housing to the urban poor, to establish the effectiveness of the 
government's low-cost housing schemes in improving access to decent, low-cost housing for the urban poor and low-income people to provide a base for the future national housing policy. Since housing is a primary component of habitat, sustainable housing development activities can directly contribute to the development of sustainable habitat. Sustainable habitat can be achieved through promoting housing development by balancing social progress, enhancing economic growth, propagating innovative technology along with conserving and protecting the environment and natural resources for future life and development.

\section{Results and Discussion}

Shelter is one of the basic needs of human beings, next only to food and clothing. Besides being a basic necessity, it is also a source of identity that has a considerable effect on the overall psychological wellbeing of the inhabitants The perception of housing has undergone some remarkable changes over the years, and has more significance in the present world than it had even two decades ago. Housing affordability remains a key hurdle preventing large-scale delivery of housing in Kabul. It would seem then that with no possibility of an increase in the subsidy amount, for those many people unable to afford to build onto their starter house, the goal of a permanent, complete dwelling remains an elusive one. Furthermore, a good number of teachers, and poor and low-income people in whose hands the capital subsidy program has put properties are also unable to afford the range of ongoing water, electricity and rate charges associated with formalized owner occupation.

Home ownership brings significant economic security and social status to a household. But for shelter-less persons it can create profound social change in their existence, by endowing them with identity, security and above all creating a feeling of being a part of society. Housing also acts as a matrix that strengthens family and community ties. The concept of home in that sense is much bigger than that of a house. It implies the provision of food, clothing, and housing with a proper environment that affords protection from the weather, offering security and wellbeing. It is also a valued place, regarded as a refuge or place of origin where a person is able to develop his social relationships. In other words, a home fulfills physical needs by providing security and shelter from weather and climate. It fulfills psychological needs by providing a sense of personal space and privacy. It fulfills social needs by providing a gathering area and communal space for the human family, the basic unit of society. In many societies, it also fulfills economic needs by functioning as a center for commercial production and thereby generating wealth. The significance of housing in social development should not be neglected in these respects. It is also a crucial component of the built environment and an intrinsic element in the economic development of all nations. In this domain, housing and development activities are also related to environmental issues and technological advancements. Housing development can be considered as a pioneering step for sustainable development that has multi-objective and multi-institutional relevance. Human settlements have to function in a sustainable way to achieve this objective of sustainable habitat. Therefore sustainable human settlement should enable residents to live in a manner that supports the state of sustainability and the principles of sustainable development and has institutional, social and economic systems that will ensure their continued existence. Sustainable-affordable housing development can thus be conceptualized as a combination of four significant aspects of sustainability, namely socio-cultural, economic, technological and environmental sustainability. We also give equal significance to the four aspects of sustainability, and want to apply them in Kabul.

The study resulted in most of the key members understanding and being aware of the concept of sustainable housing development, and perceiving it to be important in Kabul. The government and other respondents felt that project managers, consultants and contractors should play the major roles in creating and implementing sustainable housing development, instead of the clients themselves. The rising number of sustainable housing development projects being built during the reconstruction and development of Afghanistan is an acceptance of the sustainability concept among construction practitioners. However, when it comes to implementation, it seems that key players in the housing industry are not sure whether or not they have ever considered and implemented sustainable elements in housing. The respondents agreed that factors that contribute to environmental sustainability, such as choice of site, energy efficiency, efficient waste management, water conservation, etc, are important. However, when it comes to implementation, few stated that they had implemented or taken into account environmental sustainability. Most of the researchers were undecided or unaware of the effects of intense development on the local ecological system, energy efficiency, water conservation, proper sanitation and selection of environmentally friendly building materials.

Economic sustainability emphasizes financial issues of housing affordability, life cycle cost, and building lifespan, by incorporating building maintenance aspects, as well as the opportunity to optimize existing infrastructure. Still, most key players have a preference for the housing property to have larger space and more facilities. On the contrary, sustainability in the housing context does not necessarily mean larger space and more facilities. This scenario reflects that they might not fully understand the total concept of this particular element in sustainable 
housing development. As for social sustainability, it was found that for the housing industry, services such as public transport, shops, schools, work and recreational facilities and security to tenure are always provided. Elements of ease of accessibility, security to tenure and impacts of housing quality on physical and mental health of occupants are all perceived as important. However when it comes to implementation, elements such as design that aims for present and long-term use, better quality of housing and living environment, encouragement of social networks and social solidarity in neighborhood, impact of housing quality on physical and mental health of occupants, were left undecided. This can be inferred as an uncertain level of social sustainability implementation. From this analysis, it can be deduced that tenant participation is unlikely in practice. This implies the key players having minor consideration of tenant participation in housing design and management.

\subsection{Housing Finance Options}

Neither formal nor informal housing finance is significant. Bank e Millie, a state-owned commercial bank, has extended mortgage loans but has no set product — each is unique. Generally two-year loans, they range in size from $\$ 400$ to $\$ 10,000$. Most commercial banks, public and private, are keen to launch a housing finance product in the near term. These banks, along with microfinance institutions, envision a wide range of housing loan products. A product designed by Bank e Millie would range from $\$ 10,000$ to $\$ 20,000$, with a monthly payment of more than $\$ 100$ over a 20 -year term. Microfinance institutions, with the aim primarily of meeting short-term needs for home repair, envision loans ranging from $\$ 100$ to $\$ 500$, with a monthly payment of about $\$ 50$ and a maximum term of one year. [1-4], [67]-[72]

Table 1. Proposed recommendations for legal reform and infrastructure development

\begin{tabular}{|c|c|c|c|c|}
\hline & Recommendations & Time frame & Afghan stakeholders & Potential donor roles \\
\hline \multicolumn{5}{|c|}{ Legal framework } \\
\hline 1 & Enact mortgage law & Short term & $\begin{array}{l}\text { Ministry of Justice, central } \\
\text { bank, Parliament, and } \\
\text { financial institutions } \\
\text { contemplating providing } \\
\text { mortgage loans }\end{array}$ & $\begin{array}{l}\text { Provide model statutes } \\
\text { from other emerging } \\
\text { markets; offer technical } \\
\text { assistance to government } \\
\text { officials in crafting laws } \\
\text { and supporting } \\
\text { regulations }\end{array}$ \\
\hline 2 & $\begin{array}{l}\text { Enact statutes to strengthen } \\
\text { property rights and clarify } \\
\text { security of tenure }\end{array}$ & Short term & $\begin{array}{l}\text { Ministry of Justice, central } \\
\text { bank, Parliament, and } \\
\text { financial institutions } \\
\text { contemplating providing } \\
\text { mortgage loans }\end{array}$ & $\begin{array}{l}\text { Provide model statutes } \\
\text { from other emerging } \\
\text { markets; offer technical } \\
\text { assistance to government } \\
\text { officials in crafting laws } \\
\text { and supporting } \\
\text { regulations }\end{array}$ \\
\hline 3 & $\begin{array}{l}\text { Enact asset securitization law } \\
\text { and tax provisions to promote } \\
\text { development of capital market } \\
\text { and mortgage-related securities }\end{array}$ & $\begin{array}{l}\text { Medium } \\
\text { term }\end{array}$ & $\begin{array}{l}\text { Ministry of Justice, central } \\
\text { bank, Parliament, and } \\
\text { potential issuers of and } \\
\text { investors in asset-backed } \\
\text { securities }\end{array}$ & $\begin{array}{l}\text { Provide model statutes } \\
\text { from other emerging } \\
\text { markets; offer technical } \\
\text { assistance to government } \\
\text { officials in crafting laws } \\
\text { and supporting } \\
\text { regulations }\end{array}$ \\
\hline
\end{tabular}




\begin{tabular}{|c|c|c|c|c|}
\hline \multicolumn{5}{|c|}{ Infrastructure development } \\
\hline 4 & $\begin{array}{l}\text { Enhance land titling and } \\
\text { registration system, review } \\
\text { existing title records and claims, } \\
\text { simplify and reduce cost of } \\
\text { registration and transfer, and } \\
\text { integrate formal and informal } \\
\text { transfer systems }\end{array}$ & $\begin{array}{l}\text { Short to } \\
\text { medium term }\end{array}$ & $\begin{array}{l}\text { Government of } \\
\text { Afghanistan and current } \\
\text { and future property owners }\end{array}$ & $\begin{array}{l}\text { Provide examples of } \\
\text { effective reforms in } \\
\text { other markets; support } \\
\text { adoption of needed } \\
\text { technologies and } \\
\text { training of appropriate } \\
\text { staff }\end{array}$ \\
\hline 5 & $\begin{array}{l}\text { Move toward computerization of } \\
\text { all landownership records, map } \\
\text { all property boundaries, and } \\
\text { improve security of tenure for all } \\
\text { families, including those lacking } \\
\text { titles }\end{array}$ & $\begin{array}{l}\text { Medium to } \\
\text { long term }\end{array}$ & $\begin{array}{l}\text { Government of } \\
\text { Afghanistan and current } \\
\text { and future property owners }\end{array}$ & $\begin{array}{l}\text { Provide examples of } \\
\text { effective land } \\
\text { management in other } \\
\text { markets; expand support } \\
\text { in projects similar to } \\
\text { USAID's LTERA } \\
\text { Project }\end{array}$ \\
\hline 6 & $\begin{array}{l}\text { Improve lien registration system, } \\
\text { simplify and reduce cost of } \\
\text { perfecting liens on real property, } \\
\text { and clarify legal recourse in the } \\
\text { event of default }\end{array}$ & $\begin{array}{l}\text { Short to } \\
\text { medium term }\end{array}$ & $\begin{array}{l}\text { Government of } \\
\text { Afghanistan and financial } \\
\text { institutions contemplating } \\
\text { providing mortgage loans }\end{array}$ & $\begin{array}{l}\text { Provide examples of } \\
\text { effective systems in } \\
\text { other markets; support } \\
\text { training for appropriate } \\
\text { government officials and } \\
\text { staff }\end{array}$ \\
\hline 7 & $\begin{array}{l}\text { Improve lien enforcement } \\
\text { (foreclosure) system and train } \\
\text { courts and others involved in } \\
\text { enforcing liens to ensure } \\
\text { adequate protection for banks in } \\
\text { the event of default }\end{array}$ & $\begin{array}{l}\text { Medium } \\
\text { term }\end{array}$ & $\begin{array}{l}\text { Government of } \\
\text { Afghanistan and courts } \\
\text { and others charged with } \\
\text { enforcing liens }\end{array}$ & $\begin{array}{l}\text { Provide examples of } \\
\text { effective systems in } \\
\text { other markets; support } \\
\text { training for court and } \\
\text { other officials }\end{array}$ \\
\hline 8 & $\begin{array}{l}\text { Support creation of networks of } \\
\text { independent real estate } \\
\text { professionals, including property } \\
\text { appraisers and sales brokers }\end{array}$ & $\begin{array}{l}\text { Medium to } \\
\text { long term }\end{array}$ & $\begin{array}{l}\text { Financial institutions } \\
\text { involved in mortgage } \\
\text { lending, independent } \\
\text { property appraisers and } \\
\text { real estate sales brokers, } \\
\text { and potential government } \\
\text { licensing offices }\end{array}$ & $\begin{array}{l}\text { Provide examples of } \\
\text { guidelines for the } \\
\text { performance of real } \\
\text { estate professionals; } \\
\text { support training and } \\
\text { creation of professional } \\
\text { associations }\end{array}$ \\
\hline 9 & $\begin{array}{l}\text { Support creation of property } \\
\text { insurance industry and review } \\
\text { insurance law to ensure that it } \\
\text { attracts insurance companies to } \\
\text { the market }\end{array}$ & Long term & $\begin{array}{l}\text { Financial institutions } \\
\text { involved in mortgage } \\
\text { lending and insurance } \\
\text { companies }\end{array}$ & $\begin{array}{l}\text { Provide examples of } \\
\text { insurance schemes from } \\
\text { other markets; support } \\
\text { training and mentoring } \\
\text { as appropriate }\end{array}$ \\
\hline
\end{tabular}

To have final results and analysis of all this study and to develop Afghanistan's housing sector, with the overall objective of building a primary mortgage market and thus increasing the availability of affordable housing, the following future program and policy interventions are recommended:

- Strengthen the legal framework and necessary infrastructure, the prerequisites for developing the housing 
finance market. These include a sound legal environment for market participants such as financial institutions, housing developers, and property buyers and sellers; improved systems for property titling and registration and enforcement of liens; and establishment of a legal and regulatory framework for the insurance industry.

- Develop the mortgage market by enhancing capacity in commercial banks, introducing new housing finance products, and putting into place a guarantee facility to mitigate the risks for commercial banks relating to property titling and registration or enforcement of liens.

- Develop housing microfinance by creating incentives for microfinance institutions to engage in nonmortgage lending. To create such incentives, the government and donors should provide technical assistance to microfinance institutions in piloting and rolling out expanded microfinance lending for the housing sector. [67]-[72]

\subsection{Develop the Mortgage Market}

To support development of the mortgage market, the government could leverage available resources to put into place a guarantee facility to mitigate certain risks for commercial banks. Also important are efforts to enhance capacity in commercial banks and introduce new housing finance products. We should consider the following but according to the adaptation of Islamic sharia regulation:

- Create a guarantee facility to stimulate mortgage lending

- Build capacity in mortgage lending

- Perform a market segmentation exercise

- Ensure financing sources for developers

- Finance the development of rental housing

- Form a housing finance task force

For our analysis and adaptation in Kabul (in future this may improve) we can also use the most common method of examining housing affordability, the ratio test. The data are used to get the ratio of housing affordability, ratios at the national level will be examined, in terms of house price and household income differences. Specifically, the ratio test approach is interpreted as follows:

\section{Ratio of House Price to Income $=-\times \quad \%$}

Where,

House value $=$ house price $\times$ average household living spaces $\times$ household size Household Income $=$ per

$\underset{\text { capita household income }}{\text { Mortgage household size }}$ repayment to income ratio $=\frac{\text { Monthly Mortgage Repaym ents }}{\text { Household Monthly Income }} \times \quad \%$

Where,

$$
\begin{aligned}
& \text { Monthly Repayments }=\mathrm{A} \times \frac{\mathrm{r}(1+\mathrm{r})^{\wedge} \mathrm{n}}{(1+\mathrm{r})^{\mathrm{n}}-1} \\
& \mathrm{~A}=\text { Loan Principal }=\text { total house value } \times(1-\mathrm{LTV}(0.8)) \\
& \mathrm{r}=\text { monthly mortgage rate; } \\
& \mathrm{n}=\text { mortgage terms }=360 \text { months } \\
& \text { Household Monthly Income }=\frac{\text { Annual Household Income }}{12}
\end{aligned}
$$

Source: Liming Yao Nottingham, House Price, [67]-[72]

The imperfection of the method is that it does not take liquidity constraint into consideration. As the ratio approach is fully based on the standardized house quality and household size, it may not able to estimate the housing affordability ratio for all types of households and house quantities. Within a given household income, 
larger-sized households face more risky in affording housing consumption than single households, because the former require more floor space than the latter. However, this ratio fails to present such differences between household sizes.

\section{Final Potential Target Groups And Affordability analysis for housing microfinance}

About 85-90 percent of economic activities in Afghanistan are carried out in the informal sector. In addition, 80 percent of the population is rural, and the overwhelming majority of Afghan households are low income. These data suggest the large potential target population for nonmortgage loans for informal and low-cost housing. There are two groups of potential borrowers: the self-employed (entrepreneurs, farmers), found in both urban and rural areas, and wage earners (salaried workers), found mainly in urban areas (table 6). To create incentives for microfinance institutions to engage in nonmortgage lending, the government and donors should provide technical assistance to microfinance institutions in piloting and rolling out expanded microfinance lending for the housing sector.

Table 2. Potential target groups for housing microfinance

\begin{tabular}{ll}
\hline \multicolumn{1}{c}{ Group } & \multicolumn{1}{c}{ Characteristics } \\
\hline Self-employed & $\begin{array}{l}\text { Family-based businesses with fewer than } 10 \text { workers, including the owner. Most have } \\
\text { been established for several years. }\end{array}$ \\
Urban self-employed & $\begin{array}{l}\text { Engaged in a wide range of activities, including trade, services, transport, } \\
\text { home-based industry, and food production and processing. Women work from home, } \\
\text { mainly in domestic work, beauty salons, and handicrafts. }\end{array}$ \\
Rural self-employed & $\begin{array}{l}\text { Focus on agriculture, livestock, silk, day labor, transport, carpet weaving, food } \\
\text { processing, and shop keeping. } \\
\text { Wage earners }\end{array}$ \\
& Employed mainly in public sector (women made up about 21\% of public sector \\
& workforce in 2003, earning $\$ 60-800$ a month). Other wage earners work for \\
& international agencies.
\end{tabular}

Source: MISFA.

An analysis of affordability — based on clients' monthly payment, household income, and type of financing and guarantee system - indicates that poor borrowers could afford a 12-month loan amounting to $\$ 500-1,000$ to pay the cost of home improvements (table 6). Middle-income borrowers could afford a 5-year construction loan of $\$ 8,000$, requiring monthly payments of about $\$ 200$. But the provision of such loans to the targeted group would require a long-term funding mechanism to be in place for microfinance institutions. [67]-[72]

Table 3. Affordability analysis for housing microfinance

\begin{tabular}{llll}
\hline & $\begin{array}{l}\text { Minor } \\
\text { improvement }\end{array}$ & $\begin{array}{l}\text { Major } \\
\text { improvement }\end{array}$ & Construction \\
\hline Amount (U.S. dollars) & 500 & 1,000 & 8,000 \\
\hline Term (months) & 12 & 12 & 60 \\
\hline $\begin{array}{l}\text { Monthly interest rate (percent, } \\
\text { declining balance) }\end{array}$ & 2 & 2 & 1.5 \\
\hline $\begin{array}{l}\text { Monthly payment (U.S. } \\
\text { dollars) }\end{array}$ & 46 & 92 & 200 \\
\hline $\begin{array}{l}\text { Monthly household income } \\
\text { (U.S. dollars) }\end{array}$ & 184 & 368 & 800 \\
\hline Market segment & Poor & Upper poor & Middle income \\
\hline
\end{tabular}




\begin{tabular}{llll}
\hline Guarantees & Loan evaluation & $\begin{array}{l}\text { Loan evaluation; } \\
\text { Cosigner }\end{array}$ & $\begin{array}{l}\text { Loan evaluation; } \\
\text { cosigner's salary } \\
\text { deduction; institution } \\
\text { having possession of land } \\
\text { title }{ }^{\text {a }}\end{array}$ \\
\hline Requirements & $\begin{array}{lll}\text { Regular income } \\
\text { (business or } \\
\text { salary); }\end{array}$ & $\begin{array}{l}\text { Regular income } \\
\text { (business or } \\
\text { ownership of home }\end{array}$ & $\begin{array}{l}\text { Regular income (business } \\
\text { or salary); long-term } \\
\text { funding mechanism in } \\
\text { place. }\end{array}$ \\
\hline
\end{tabular}

Data Source: Prepared by Shore Bank International consultant

Table 4. Advantages and disadvantages of potential housing finance providers

\begin{tabular}{|c|c|c|}
\hline Providers & Advantages & Disadvantages \\
\hline $\begin{array}{l}\text { Microfinance } \\
\text { institutions }\end{array}$ & $\begin{array}{l}\text { Experience in lending to low income } \\
\text { families } \\
\text { - Countrywide presence } \\
\text { - A desire to launch housing loan } \\
\text { products }\end{array}$ & $\begin{array}{l}\text { - Minimal experience in housing } \\
\text { microfinance }\end{array}$ \\
\hline Commercial banks & $\begin{array}{l}\text { - } \text { Access to capital } \\
\text { - Branch network in urban area }\end{array}$ & $\begin{array}{l}\text { - } \text { Risk averse } \\
\text { - Unwilling to lend to low income } \\
\text { households } \\
\text { - Lack of lending technologies for } \\
\text { entrepreneurs with irregular income }\end{array}$ \\
\hline NGOs & $\begin{array}{l}\text { - Countrywide presence } \\
\text { Ability to build strategic alliances } \\
\text { with microfinance institutions to } \\
\text { provide technical assistance in } \\
\text { construction practices and other } \\
\text { nonfinancial services }\end{array}$ & $\begin{array}{l}\text { - } \quad \text { Lack of experience in lending } \\
\text { - Perception that a loan would be a } \\
\text { grant and thus not repaid by clients }\end{array}$ \\
\hline Moneylenders & - Countrywide presence & $\begin{array}{l}\text { No experience in housing lending } \\
\text { except for short-term (12-month) } \\
\text { loans } \\
\text { - Costly source of loans } \\
\end{array}$ \\
\hline Government & & $\begin{array}{ll}\text { - } & \text { Public institution requiring } \\
\text { resources and time to get started } \\
\text { - } & \text { Risk of politicization and eventual } \\
\text { bankruptcy } \\
\text { - Could send negative signal to } \\
\text { microfinance market }\end{array}$ \\
\hline
\end{tabular}

Source: Prepared by Shore Bank International consultant based on review of various studies and discussions with MISFA. 
Table 5. Kabul housing typology

\begin{tabular}{|c|c|c|c|}
\hline Type of development & Dwelling Design & $\%$ of plots occupied in the settlement & Type Number \\
\hline \multirow{8}{*}{ Formal } & \multirow{2}{*}{$\begin{array}{l}\text { Apartments } \\
\text { Townhouses }\end{array}$} & Fully occupied $80 \%$ to $100 \%$ & 1 \\
\hline & & Fully occupied $80 \%$ to $100 \%$ & 2 \\
\hline & \multirow{3}{*}{ Detached Houses } & Occupied at between $50 \%$ to $79 \%$ & 3 \\
\hline & & Occupied at between $20 \%$ to $49 \%$ & 4 \\
\hline & & Fully occupied $80 \%$ to $100 \%$ & 5 \\
\hline & \multirow{3}{*}{ Courtyard Houses } & Fully occupied $80 \%$ to $100 \%$ & 6 \\
\hline & & Occupied at between $50 \%$ to $79 \%$ & 7 \\
\hline & & Occupied at between $20 \%$ to $49 \%$ & 8 \\
\hline \multirow{9}{*}{ Informal } & \multirow{3}{*}{ Detached Houses } & Fully occupied $80 \%$ to $100 \%$ & 9 \\
\hline & & Occupied at between $50 \%$ to $79 \%$ & 10 \\
\hline & & Occupied at between $20 \%$ to $49 \%$ & 11 \\
\hline & \multirow{3}{*}{ Courtyard Houses } & Fully occupied $80 \%$ to $100 \%$ & 12 \\
\hline & & Occupied at between $50 \%$ to $79 \%$ & 13 \\
\hline & & Occupied at between $20 \%$ to $49 \%$ & 14 \\
\hline & \multirow{3}{*}{ Houses on slopes } & Fully occupied $80 \%$ to $100 \%$ & 15 \\
\hline & & Occupied at between $50 \%$ to $79 \%$ & 16 \\
\hline & & Occupied at between $20 \%$ to $49 \%$ & 17 \\
\hline
\end{tabular}

In addition it is estimated that 10,000 people or 4,000 households live in tents

Data Source: Prepared by Shore Bank International consultant [5] 
Table 6. Socio-environmental and demographic survey of 60 houses

\begin{tabular}{|c|c|c|c|c|c|c|}
\hline \multirow[b]{2}{*}{ NO } & \multirow{2}{*}{\multicolumn{3}{|c|}{ Specifications }} & \multirow{3}{*}{\begin{tabular}{|l|} 
Zone 1 \\
G1 \\
Total \\
\end{tabular}} & \multirow{3}{*}{\begin{tabular}{|r|} 
Zone 2 \\
G1,G2 \\
Total \\
\end{tabular}} & \multirow{3}{*}{\begin{tabular}{|c|} 
Zone 3 \\
G1,G2,G3 \\
Total \\
\end{tabular}} \\
\hline & & & & & & \\
\hline \multirow{5}{*}{1} & \multirow{5}{*}{\multicolumn{2}{|c|}{ Plot Area }} & & & & \\
\hline & & & $(100-299) \mathrm{m}^{2}$ & 7 & 1 & 0 \\
\hline & & & $(300-599) \mathrm{m}^{2}$ & 16 & 10 & 10 \\
\hline & & & $(600-900) \mathrm{m}^{2}$ & 0 & 6 & 3 \\
\hline & & & more than $900 \mathrm{~m}^{2}$ & 0 & 4 & 5 \\
\hline \multirow{7}{*}{2} & \multirow{7}{*}{\multicolumn{2}{|c|}{ House Age }} & Less than 10 Years & 22 & 7 & 4 \\
\hline & & & $10-20$ Years & 0 & 4 & 1 \\
\hline & & & $21-30$ Years & 0 & 4 & 5 \\
\hline & & & $31-40$ Years & 0 & 1 & 4 \\
\hline & & & 41-50 Years & 0 & 1 & 2 \\
\hline & & & 51-60 Years & 0 & 4 & 1 \\
\hline & & & More than 60 Years & 0 & 1 & 1 \\
\hline \multirow{7}{*}{3} & \multirow{7}{*}{\multicolumn{2}{|c|}{ Period of Stay }} & Less than 10 Years & 6 & 11 & 6 \\
\hline & & & $10-20$ Years & 11 & 4 & 4 \\
\hline & & & $21-30$ Years & 4 & 3 & 2 \\
\hline & & & $31-40$ Years & 0 & 0 & 3 \\
\hline & & & 41-50 Years & 2 & 1 & 1 \\
\hline & & & 51-60 Years & 0 & 3 & 1 \\
\hline & & & More than 60 Years & 0 & 0 & 1 \\
\hline \multirow{4}{*}{4} & \multirow{4}{*}{\multicolumn{2}{|c|}{ No. of Floors }} & 1 Floor & 12 & 9 & 2 \\
\hline & & & 2 Floors & 4 & 7 & 13 \\
\hline & & & 3 Floors & 3 & 5 & 1 \\
\hline & & & 4 Floors & 3 & 1 & 2 \\
\hline \multirow{5}{*}{5} & & & 1 family per house & 10 & 11 & 5 \\
\hline & & & 2 families per house & 8 & 6 & 9 \\
\hline & & No. of Family & 3 families per house & 2 & 2 & 2 \\
\hline & & & 4 families per house & 3 & 3 & 2 \\
\hline & & & More than 4 families & 0 & 0 & 0 \\
\hline & & & Below 9 years & 78 & 55 & 41 \\
\hline & & & $10-19$ years & 80 & 73 & 47 \\
\hline 6 & & No. of Family members & $20-39$ years & 62 & 61 & 67 \\
\hline & & & $40-59$ years & 46 & 43 & 38 \\
\hline & & & Above 60 years & 8 & 13 & 11 \\
\hline & & & 2-4 Rooms & 1 & 6 & 1 \\
\hline 7 & & Alo of Ronms & 5-7 Rooms & 12 & 6 & 12 \\
\hline ' & & NO. OT Kooms & $8-10$ Rooms & 5 & 2 & 3 \\
\hline & & & More than 10 Rooms & 5 & 8 & 2 \\
\hline 8 & & Type of ownership & Owner & 18 & 16 & 15 \\
\hline 0 & & туре оा оw & Rental & 5 & 6 & 3 \\
\hline & & & Pashtun & 10 & 20 & 17 \\
\hline 9 & & Ethnicity & Tajik & 8 & 2 & 1 \\
\hline & & & Hazara & 7 & 1 & 0 \\
\hline & & & Gov. employee & 9 & 7 & 9 \\
\hline 10 & & Social Group & Per. sector employee & 4 & 5 & 3 \\
\hline & & & Unemployee & 11 & 10 & 6 \\
\hline & & Living space & $\begin{array}{r}\text { YES } \\
\end{array}$ & 22 & 15 & 18 \\
\hline & & Living space & NO & 1 & 7 & 0 \\
\hline & o & No of rooms & YES & 23 & 15 & 17 \\
\hline & 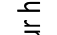 & 年 & NO & 0 & 7 & 1 \\
\hline & $\bar{\partial}$ & Corvisor & YES & 23 & 16 & 15 \\
\hline & $\widehat{E}$ & services & NO & 0 & 5 & 3 \\
\hline & 3 & Privacy & YES & 15 & 10 & 16 \\
\hline 11 & $\frac{0}{\frac{0}{\pi}}$ & Privacy & NO & 6 & 12 & 2 \\
\hline $1 \perp$ & 艺 & Height & YES & 21 & 16 & 15 \\
\hline & $\stackrel{0}{E}$ & Heignt & NO & 1 & 5 & 3 \\
\hline & $\underline{\overline{3}}$ & Davlight & YES & 23 & 19 & 18 \\
\hline & $\bar{\Xi}$ & & NO & 0 & 3 & 0 \\
\hline & $\bar{\partial}$ & Orientation & YES & 19 & 16 & 16 \\
\hline & s & Smentation & NO & 2 & 6 & 2 \\
\hline & ด & Sound & YES & 8 & 7 & 14 \\
\hline & & souna & NO & 14 & 15 & 4 \\
\hline
\end{tabular}




\begin{tabular}{|c|c|c|c|c|c|c|}
\hline \multirow{2}{*}{ NO } & \multirow{2}{*}{\multicolumn{3}{|c|}{ Specifications }} & \multirow{2}{*}{$\begin{array}{c}\text { Zone } 1 \\
\text { G1 } \\
\text { Total }\end{array}$} & \multirow{2}{*}{$\begin{array}{c}\text { Zone } 2 \\
\text { G1,G2 } \\
\text { Total }\end{array}$} & \multirow{3}{*}{$\begin{array}{c}\text { Zone } 3 \\
\text { G1,G2,G3 } \\
\text { Total } \\
0\end{array}$} \\
\hline & & & & & & \\
\hline \multirow{7}{*}{12} & \multirow{10}{*}{ 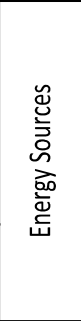 } & \multirow{7}{*}{$\begin{array}{c}\text { What System do you use for } \\
\text { heating? }\end{array}$} & Con Heating Syctom & 0 & 0 & \\
\hline & & & Gas & 9 & 6 & 12 \\
\hline & & & Fuel & 1 & 4 & 4 \\
\hline & & & Wood & 15 & 17 & 14 \\
\hline & & & Sandali & 17 & 2 & 4 \\
\hline & & & Taba-Khana & 0 & 0 & 1 \\
\hline & & & Electricity & 15 & 18 & 12 \\
\hline \multirow{3}{*}{13} & & \multirow{3}{*}{$\begin{array}{l}\text { What system do you use for } \\
\text { cooling? }\end{array}$} & Fan & 16 & 17 & 15 \\
\hline & & & A.C & 7 & 9 & 7 \\
\hline & & & Natural & 19 & 15 & 9 \\
\hline \multirow{14}{*}{14} & \multirow{14}{*}{ 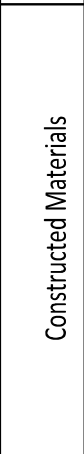 } & \multirow{2}{*}{ Foundation } & Concrete & 12 & 5 & 2 \\
\hline & & & Stone & 11 & 17 & 16 \\
\hline & & & Concrete & 11 & 7 & 2 \\
\hline & & Main structure & Brick & 11 & 15 & 16 \\
\hline & & Ext. walls & Brick & 22 & 22 & 18 \\
\hline & & & Brick & 22 & 21 & 18 \\
\hline & & Int. walls & Wood & 0 & 0 & 0 \\
\hline & & & Concrete & 8 & 8 & 4 \\
\hline & & Roof & Metal & 9 & 5 & 4 \\
\hline & & & Wood & 6 & 11 & 10 \\
\hline & & & Wood & 20 & 17 & 18 \\
\hline & & Doors & PVC & 3 & 4 & 0 \\
\hline & & Windowe & Wood & 12 & 16 & 18 \\
\hline & & Windows & PVC/ Double glass & 11 & 6 & 0 \\
\hline 15 & & he families living together are & YES & 21 & 16 & 13 \\
\hline 15 & & relatives? & NO & 0 & 5 & 4 \\
\hline 16 & The & families living together are from & YES & 3 & 12 & 7 \\
\hline 16 & & different ethnics? & NO & 19 & 9 & 10 \\
\hline 17 & Are t & the families living together using & YES & 1 & 9 & 6 \\
\hline $1 /$ & & from separate access ways? & NO & 22 & 12 & 11 \\
\hline 18 & & & YES & 4 & 9 & 5 \\
\hline 18 & Do & you have separate guest house? & NO & 19 & 13 & 13 \\
\hline 19 & Do yo & u have separate storage?( Pyada- & YES & 16 & 13 & 12 \\
\hline & & khana) & NO & 6 & 9 & 6 \\
\hline 20 & & Youften use from flat roof? & YES & 21 & 10 & 7 \\
\hline 20 & & o you orten use trom trat root? & NO & 2 & 12 & 11 \\
\hline 21 & Do & you have hall for parties in your & YES & 4 & 9 & 9 \\
\hline 21 & & house? & NO & 19 & 13 & 9 \\
\hline & & Sidewalk condition & YES & 17 & 14 & 13 \\
\hline & & slaewalk conaltion & NO & 6 & 8 & 5 \\
\hline & & Road condition & YES & 18 & 12 & 12 \\
\hline & & Road condition & NO & 5 & 10 & 6 \\
\hline & & Water Condition & YES & 20 & 15 & 12 \\
\hline & & Water Condition & NO & 3 & 7 & 6 \\
\hline & & Electricity Condition & YES & 22 & 16 & 17 \\
\hline & $\overline{\frac{+}{3}}$ & Electricity Condition & NO & 1 & 6 & 1 \\
\hline & б & Green Arez & YES & 7 & 9 & 9 \\
\hline 22 & 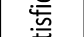 & Green Area & NO & 16 & 13 & 9 \\
\hline 22 & 苋 & Plavaround & YES & 6 & 6 & 8 \\
\hline & 오 & Playground & $\mathrm{NO}$ & 17 & 16 & 9 \\
\hline & $\vec{\Phi}$ & Parking & YES & 5 & 9 & 9 \\
\hline & & Parking & $\mathrm{NO}$ & 18 & 13 & 9 \\
\hline & & Kindergarten/School & YES & 16 & 13 & 15 \\
\hline & & Kindergarten/School & $\mathrm{NO}$ & 6 & 9 & 3 \\
\hline & & Shons & YES & 21 & 20 & 17 \\
\hline & & Snops & $\mathrm{NO}$ & 2 & 2 & 1 \\
\hline & & Mosque & YES & 22 & 22 & 16 \\
\hline & & Mosque & $\mathrm{NO}$ & 0 & 0 & 1 \\
\hline 23 & Whi & ch olectricity source do you use? & Public & 22 & 22 & 18 \\
\hline 23 & $\mathrm{~V} n \mathrm{ni}$ & ch electricity source do you use? & Private & 1 & 0 & 0 \\
\hline 24 & & hich water source do you use? & Public & 21 & 12 & 12 \\
\hline 24 & & nich water source do you use? & Private & 2 & 10 & 6 \\
\hline 25 & Wha & $\begin{array}{l}\text { t improvement have you brought } \\
\text { in your house? Why? (date) }\end{array}$ & & & & \\
\hline
\end{tabular}


Table 7. Calculation of the additional absorption capacity of the housing stock

\begin{tabular}{|c|c|c|c|c|c|c|c|c|}
\hline & 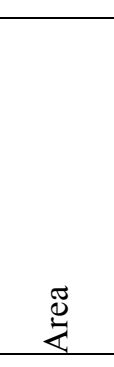 & 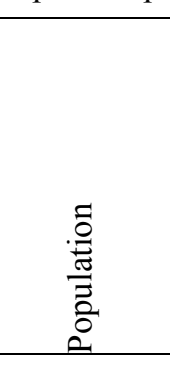 & 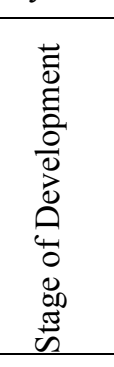 & 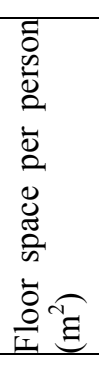 & 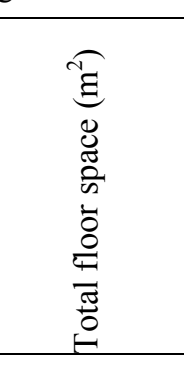 & 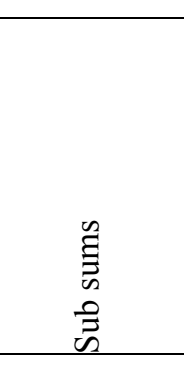 & 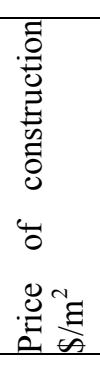 & 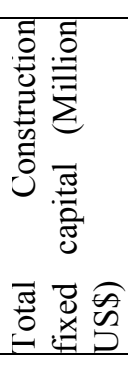 \\
\hline Airport & 4.39 & - & $100 \%$ & - & - & & & \\
\hline Non Residential & 36.30 & 54,456 & $100 \%$ & - & - & & & \\
\hline Formal Apartments & 1.8 & 90,749 & $100 \%$ & 7.33 & 665,480 & 665,480 & 200 & 133 \\
\hline $\begin{array}{l}\text { Formal detached in } \\
\text { development }\end{array}$ & 4.28 & 21,021 & $30 \%$ & 10.00 & 210,213 & & & - \\
\hline $\begin{array}{lll}\text { Formal } & \text { detached } & 70 \% \\
\text { occupied } & & \\
\end{array}$ & 3.77 & 43,243 & $70 \%$ & 10.00 & 432,427 & $5,171,414$ & 200 & 1,034 \\
\hline Formal detached fully built & 22.64 & 370,907 & $100 \%$ & 12.21 & $4,528,774$ & & & - \\
\hline Formal Terrace Housing & 0.17 & 5,186 & $100 \%$ & 16.11 & 83,557 & 83,557 & 150 & 13 \\
\hline $\begin{array}{l}\text { Informal Courtyards in } \\
\text { Development }\end{array}$ & 4.88 & 60,369 & $30 \%$ & 6.00 & 362,214 & & & - \\
\hline $\begin{array}{l}\text { Informal Courtyards } 70 \% \\
\text { Occupied }\end{array}$ & 21.85 & 631,061 & $70 \%$ & 6.00 & $3,786,364$ & & & - \\
\hline $\begin{array}{l}\text { Informal Courtyard Fully } \\
\text { built }\end{array}$ & 31.23 & $1,288,208$ & $100 \%$ & 7.27 & $9,368,785$ & $14,045,235$ & 80 & 1,124 \\
\hline $\begin{array}{l}\text { Informal Detached in } \\
\text { Development }\end{array}$ & 0.05 & 602 & $30 \%$ & 6.00 & 3,610 & & & - \\
\hline $\begin{array}{l}\text { Informal Detached about } \\
70 \% \text { Occupied }\end{array}$ & 3.26 & 86,654 & $70 \%$ & 6.00 & 519,922 & & & - \\
\hline Informal detached fully built & 0.02 & 686 & $100 \%$ & 6.32 & 4,339 & & & - \\
\hline $\begin{array}{l}\text { Informal Slopes in } \\
\text { Development }\end{array}$ & 1.46 & 19,902 & $30 \%$ & 5.00 & 99,510 & & & - \\
\hline $\begin{array}{lll}\text { Informal } & \text { Slopes } & 70 \% \\
\text { occupied } & & \\
\end{array}$ & 3.23 & 102,513 & $70 \%$ & 5.00 & 512,566 & $2,615,522$ & 80 & 209 \\
\hline \multirow[t]{2}{*}{ Informal Slopes Fully Built } & 5.57 & 252,229 & $100 \%$ & 7.94 & $2,003,446$ & & & - \\
\hline & 144.91 & $3,027,783$ & & & $22,581,207$ & $22,581,207$ & & 2,513 \\
\hline
\end{tabular}

Data Source: Prepared by Shore Bank International consultant [5]

\subsection{Adoptable Matching Housing Assistance to Afghan Needy Families}

Affordable housing may exist within a continuum that includes various types of accommodation and housing tenures. This includes crisis accommodation, social housing, renting in the private sector and home ownership. There is often an assumption that households move in a linear manner, through a continuum from government or some international donors subsidized accommodation to private rental to home ownership, becoming increasingly financially secure and stable in their accommodation. This is in fact not the case, and households may move anywhere within the continuum, depending on their particular circumstances. The diagram below, adapted from National Shelter's Policy Priorities, highlights the various support options, which households may 
require to address different housing needs. The type of support households in housing stress may require will vary according to their particular circumstances and needs of Afghan community. Some groups are impacted more acutely by the shortage of affordable housing, including people with war disabilities, martyred families, the jobless and destitute, seniors (particularly older women) and others.

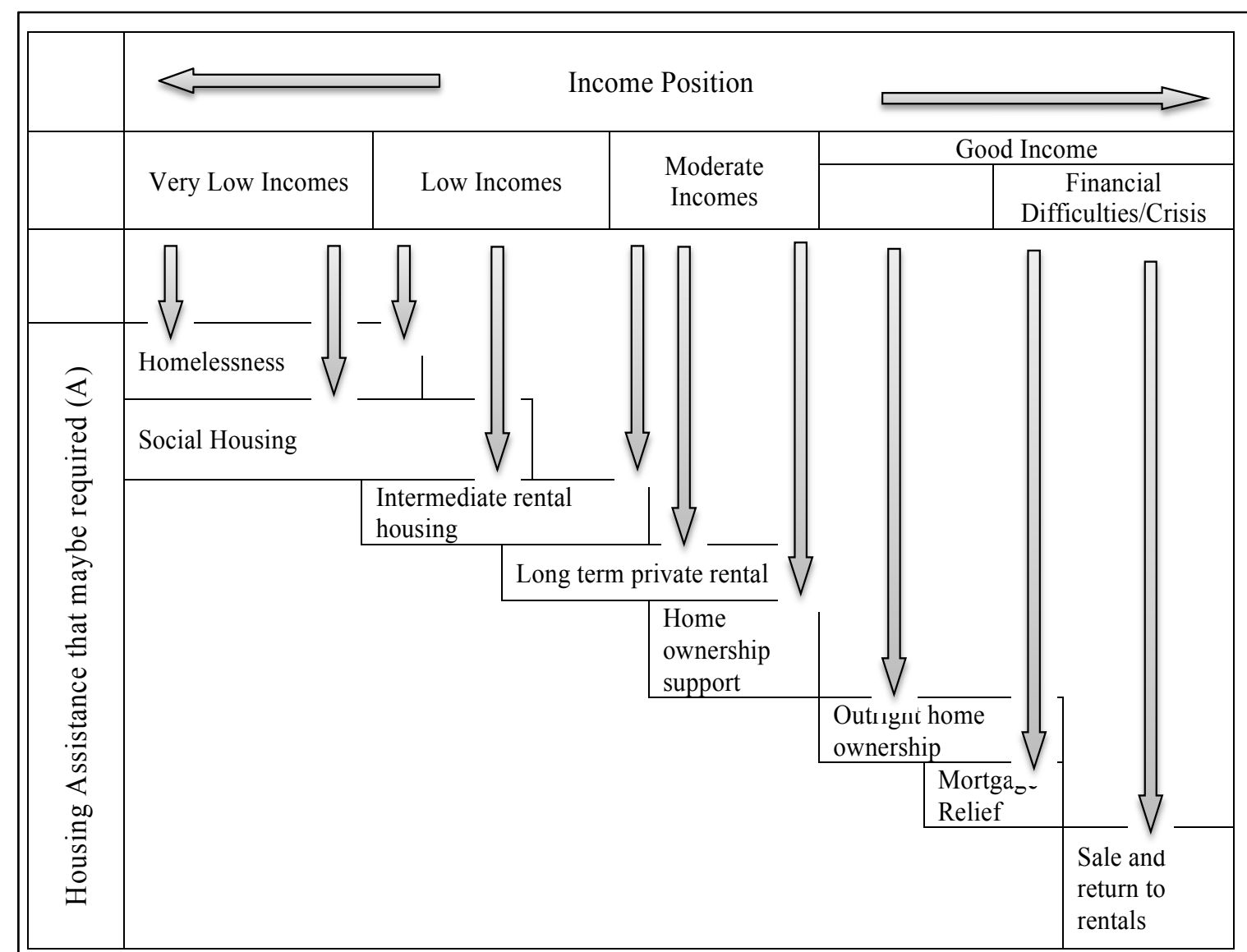

Note: A) This Diagram is intended to show the types of Housing assistance in Kabul city may be required by people depending income (Because not existing of Average standard income range between People) Not all people on each income will require support.

Figure 13. Adoptable matching housing assistance level and income position to Afghan needy families Sources (Housing Sustainability and Affordability for the Future, 2013 - 2015), [67]-[72] 
Table 8. Kabul - Distribution of Housing Stock by Types and Sub-Types (2004)

\begin{tabular}{|c|c|c|c|c|c|c|}
\hline \multirow[t]{4}{*}{ Total } & \multicolumn{2}{|c|}{ Residential Land use } & Area & Population & $\%$ Area & $\begin{array}{l}\% \\
\text { Population }\end{array}$ \\
\hline & \multicolumn{2}{|l|}{ Formal } & 32.66 & 531,104 & $31 \%$ & $18 \%$ \\
\hline & \multicolumn{2}{|l|}{ Informal } & 71.56 & $2,442,223$ & $69 \%$ & $82 \%$ \\
\hline & \multicolumn{2}{|c|}{ Total Residential areas } & 104.22 & $2,973,328$ & $100 \%$ & $100 \%$ \\
\hline \multicolumn{7}{|l|}{ Formal } \\
\hline & \multicolumn{2}{|l|}{ Apartments } & 1.8 & 90,747 & $6 \%$ & $17 \%$ \\
\hline & Detached & $\begin{array}{l}\text { Occupied at between } 20 \text { to } \\
49 \%\end{array}$ & 4.28 & 21,021 & $13 \%$ & $4 \%$ \\
\hline & - & $\begin{array}{l}\text { Occupied at between } 50 \text { to } \\
79 \%\end{array}$ & 3.77 & 43,243 & $12 \%$ & $8 \%$ \\
\hline & - & Fully occupied $80 \%$ to $100 \%$ & 22.64 & 370,907 & $69 \%$ & $70 \%$ \\
\hline & \multirow{2}{*}{\multicolumn{2}{|c|}{ Townhouses }} & 0.17 & 5,186 & $1 \%$ & $1 \%$ \\
\hline & & & 32.66 & 531,104 & $100 \%$ & $100 \%$ \\
\hline & \multicolumn{2}{|c|}{ Total Formal as \% Total residential } & 32.66 & $1,979,638$ & $56 \%$ & $67 \%$ \\
\hline \multirow[t]{15}{*}{ Informal } & & & 4.88 & 60,389 & $8 \%$ & $3 \%$ \\
\hline & & & 21.85 & 631,061 & $38 \%$ & $32 \%$ \\
\hline & & & 31.23 & $1,288,208$ & $54 \%$ & $65 \%$ \\
\hline & & & 57.96 & $1,979,638$ & $100 \%$ & $100 \%$ \\
\hline & \multicolumn{2}{|c|}{ Total Courtyard as \% Total residential } & 57.96 & $1,979,638$ & $56 \%$ & $67 \%$ \\
\hline & \multirow[t]{2}{*}{ Detached } & $\begin{array}{l}\text { Occupied at between } 20 \text { to } \\
49 \%\end{array}$ & 0.05 & 602 & $2 \%$ & $1 \%$ \\
\hline & & $\begin{array}{l}\text { Occupied at between } 50 \text { to } \\
79 \%\end{array}$ & 3.26 & 86,654 & $98 \%$ & $99 \%$ \\
\hline & \multirow[t]{2}{*}{-} & \multirow[t]{2}{*}{ Fully occupied $80 \%$ to $100 \%$} & 0.02 & 686 & $1 \%$ & $1 \%$ \\
\hline & & & 3.33 & 87,941 & $100 \%$ & $100 \%$ \\
\hline & \multicolumn{2}{|c|}{ Total Detached as \% of Total Residential } & 3.33 & 87,941 & $3 \%$ & $3 \%$ \\
\hline & \multirow{2}{*}{$\begin{array}{l}\text { Houses on } \\
\text { slopes }\end{array}$} & $\begin{array}{l}\text { Occupied at between } 20 \text { to } \\
49 \%\end{array}$ & 1.46 & 19,902 & $14 \%$ & $5 \%$ \\
\hline & & $\begin{array}{l}\text { Occupied at between } 50 \text { to } \\
79 \%\end{array}$ & 3.23 & 102,513 & $31 \%$ & $27 \%$ \\
\hline & \multirow[t]{2}{*}{-} & \multirow[t]{2}{*}{ Fully occupied $80 \%$ to $100 \%$} & 5.57 & 252,229 & $54 \%$ & $67 \%$ \\
\hline & & & 10.26 & 374,644 & $100 \%$ & $100 \%$ \\
\hline & \multicolumn{2}{|c|}{ Total Slopes at \% of Total Residential } & 10.25 & 374,644 & $10 \%$ & $13 \%$ \\
\hline
\end{tabular}

\section{Conclusions}

This study aimed at developing a comprehensive innovative approach for investigating and adopting a sustainable and affordable housing policy in the city of Kabul. Such an approach was based on introducing a new paradigm of research: trans-disciplinarity as a form of inquiry that crosses the boundaries of different disciplines. An argument on the impact of trans-disciplinary thinking on understanding sustainable and affordable housing was developed and placed within the perspective of how lifestyle theories and their underlying concepts can be incorporated into a comprehensive investigatory process. In turn, a framework of inquiry was developed which reflected on affordable housing knowledge types. The proposed framework was conceptualized and translated into a survey tool, which was then devised in the form of a questionnaire to be implemented in the context of Kabul. The tool was tested in the three sites. The importance of such an approach lies in the value of how trans-disciplinary 
thinking in built environment-related realms can be introduced, where the boundaries of different disciplines are crossed. In essence, planning and architectural aspects, social and cultural issues, and cost and financial issues are all incorporated into one mechanism toward a comprehensive inquiry on affordable housing.

Many of the objectives of affordable housing closely align with the objectives of sustainability, such as location close to public transport and social and community facilities, compact design, consideration of climate and solar orientation. Having said that, there are also some objectives that are quite opposite to each other, such as the fact that eco-efficient housing is expensive, and it is difficult to achieve affordability without financial support from the government. Even though housing sustainability is as important as housing affordability, it is necessary to give priority to affordability for low-income households. Therefore, to make housing sustainable for everyone, sustainability criteria will not be the same across various socio-economic groups. Affordable housing and social sustainability could easily be achieved by providing better design in the public realm, but environmental and economic sustainability might be difficult to achieve due to the high cost of sustainable housing. Choguill (2007) argues that 50 years of housing policy development has not solved the problem of affordability and every year inadequate housing in the developing world is increasing. Therefore, it is hard to believe that just because we label something "sustainable," it will improve affordability (Choguill, 2007).

Even though we tend to think of affordable housing as a distinct and identifiable sector, in fact, it is little more than one sector of the overall housing development. Although we can treat these two issues in isolation, they are invariably interrelated and we are unlikely to achieve success in one without succeeding in other. In the same way, some of the principles of sustainability are aligned with affordable housing objectives and housing as a whole sector. Therefore, it is quite unlikely that success will be achieved in sustainable-affordable housing without succeeding in housing as a whole incorporating issues of sustainability. However, the scale of the social, economic and environmental sustainability will vary based on the housing affordability of households from place to place. It is unlikely, without using design criteria such as the new urbanism concept and the development of a housing policy including a sustainability agenda, and government subsidies to achieve sustainability, that it will be easy to achieve sustainable, affordable housing.

Shelter is one of the basic needs of human beings next only to food and clothing. Besides being a basic necessity, it is also a source of identity that has a considerable effect on the overall psychological wellbeing of the inhabitants. The perception of housing has undergone some remarkable changes over the years and has more significance in the present world than it had even two decades ago. Home ownership brings significant economic security and social status to a household. But for shelter-less persons it can create profound social change in their existence, by endowing them with identity, security, and above all creating a feeling of being a part of society. Housing also acts as a matrix that strengthens family and community ties.

Sustainable-affordable housing development can thus be conceptualized as a combination of four significant aspects of sustainability, namely socio-cultural, economic, technological and environmental sustainability After Pope et al. (2004), we also consider the four aspects of sustainability of equal significance. The interdependence and equality of these four factors are considered as the assumptions of this concept in Kabul.

This research integrates different perspectives to understand the housing problems in Afghanistan, especially in Kabul, and to develop improved strategies leading to sustainable-affordable housing. These perspectives combine a technological view, mainly concentrating on building materials, with non-technical aspects such as the socio-cultural view of the beneficiaries, the economic aspects of the building process, and policy aspects as seen from a government perspective. This Sustainable and Affordable Housing Policy Principles and Formulation Adoptable study will be the foundation of national housing policy in the future in Afghanistan.

Stabilized social culture can be seen easily in societies that have old and established forms of social and urban life, because of their antiquity. The architecture of human housing depends on a people's way of living, perception and understanding and geographical features. Generally architecture represents the growth of human perception and belief manifested in the building of one's residence. New building principles, because of the development of tools, equipment and new materials, have been more applied today. The product of this sustainable designing is dependence upon energy, originality, and a lack of affordability. The development of technology has affected all aspects of human life, and the irregular mixing of culture has destroyed most useful social values. Modern architecture and Western construction technology will affect our future architecture, especially Afghan architecture, because separation of architecture from tradition and previous experience has deleted humanism and attention to native human spirit from architecture. In this situation, Islam has no impact on the architecture of housing, and the conscious desire for western architecture will increase day by day. The dominant form in Muslim contemporary planning is the western pattern that has lost its utility even in industrial nations. These western 
patterns are in serious confrontation with Islam as a philosophy of life.

Coordinating the efforts of stakeholders is essential to lay the foundations for the development of both mortgage and nonmortgage housing products. Forming a housing finance task force to facilitate solutions to the larger policy and regulatory challenges facing the housing finance sector would be an appropriate step in that direction. These policy activities, combined with technical assistance for banks and microfinance institutions and appropriate long-term funding mechanisms, would bring the Afghan housing finance sector closer to serving the needs of Afghan citizens.

\section{Acknowledgments}

Mr. Sean McPherson, Assistant Professor, Department of Art, Bridgewater State University, U.S.A. supports this paper as editor on English writing assistance. We thank him for his cooperation.

Notes

Note. 1. Stanley Ira Hallet and Rafi Samizay. (1980) Traditional Architecture of Afghanistan, Garland STM Publishing.

Note. 2. Rafi Samai Zai. (1981) Islamic Architecture in Herat: A Study Towards Conservation, Research Section of International Project for Heart Monuments, Ministry of Information and Culture, Democratic Republic of Afghanistan.

Note. 3. Jennifer Brick. (2008) "The Political Economy of Customary Village Organizations in Rural Afghanistan." Paper prepared for the Annual Meeting of the Central Eurasian Studies Society, Washington, D.C., September 2008.

Note 4. Bashir A. Kazimee. "The Role of Environmental and Cultural Heritage in Rebuilding The Afghan Cities." In Instant Cities: Emergent Trends in Architecture and Urbanism in the Arab World. Edited by A. Moustafa, J. Al-Quawasmi and K. Mitchell, School of Architecture, American University of Sharjah, UAE, CSAAR Press, 2008: pp. 537-548.

Note 5. World Bank (2005), "Kabul: Urban Land Crisis, A Policy Note", World Bank.

Note 6. RECS International and Yachiyo Engineering Co., Ltd. (2011), "Draft Kabul City Master Plan". Japan Internationa Cooperation Agency 2011.

Note 7. Bashir A. Kazimee and James Mcquillan. (2001) "The Living Traditions of the Afghan Courtyard and Aiwan," Traditional Dwellings and Settlements Review 13.2, pp. 23-34.

Note 8. Andrew, H., Buchanan, Honey, B, G., 1994. Energy and carbon dioxide implications of building construction, Energy and Buildings, 20, pp 205-217.

Note 9. Ankara, 1976. Studies of black silica produced under varying conditions, PhD Thesis, University of California, Berkeley (cited in Bui, 2001).

Note 10. Debnath, A., Singh, S, V ., Singh, Y, P ., 1995. Comparative assessment of energy requirements for different types of residential buildings in India, Energy and Buildings, 23, pp 141-146.

Note 11. Keeney, Ralph L. 1988. "Structuring objectives for problems of public interest" in: Operations Research, Vol. 36, No. 3 May-June pp.396-405.

Note 12. Asian Development Bank (ADB), 2000. Report and recommendation of the president to the board of directors on four proposed loans to the housing and urban development corporation, National housing bank, Housing Development Finance corporation, and ICICI for the housing finance II project in India. RRP: IND 30204. http://www.adb.org/Documents/RRPs/IND/rrp-1758-ind.pdf

Note 13. Chani, P, S., Najamuddin, Kaushik, S, K.., 2003. Comparative analysis of embodied energy rates for walling elements in India. IE (I) Journal- AR, 84, page 47-50. (http://www.ieindia.org/publish/ar/1003/oct03ar3.pdf, last accessed on 28/08/2006)

Note 14. Chen, T,Y., Burnett, J., Chau, C,K., 2001. Analysis of embodied energy use in the residential building of Hong Kong. Energy, 26, pp 323-340.

Note 15. Erguden, S 2001. Low cost housing, Policies and constraints in developing countries. Spatial information for sustainable development, International conference, Nairobi, Kenya.

Note 16. Boulder straw bale code, Ordinance No: 5891, An ordinance amending chapter 10-5, BR.C.1981, Concerning alternative building materials, including adobe and Straw bale construction and recycled lumber, (http://www.dcat.net/resources/Boulder_Straw_Bale_Code.pdf, last accessed on 28/08/2006) 
Note 17. CIB (International Council for Research and Innovation in Building and Construction) and UNEP-IETC., 2002. Agenda 21 for Sustainable construction in Developing countries, a discussion document, Published by the CSIR building and construction technology, South Africa.

Note 18. Dreze and Sen, A., 1988 cited in Kannan, K, P., 1999. Poverty alleviation as advancing basic human capabilities: Kerala's achievements compared, Centre for Development Studies, Thiruvananthapuram.

Note 19. Bhattacharya, K, P 1994. Affordable housing, Infrastructure and urban development. Habitat International 18 (2), 99-101.

Note 20. Glaeser, B (1995). Housing, Sustainable Development and the Rural Poor A study of Tamil Nadu. SAGE Publications, New Delhi.

Note 21. UNCHS - GSS 2000, The global strategy for shelter to the year, HS/185.

Note 22. Islam, N (1996). Sustainability issues in a low-income country: Bangladesh. Habitat International 20 (3) 377- 388 .

Note 23. Ebsen, C and Ramboll, B (2000). International review of low-cost sustainable housing projects. Proceedings: Strategies for a Sustainable built environment.

Note 24. Veron, R (2001). The new Kerala Model: Lessons for sustainable development. World Development29 (4) 601-617.

Note 25. Barakat, S. and Ellis, S. (eds.) (1996) Towards Improved Shelter and Environment for Refugees and Displaced Persons within the Post-Yugoslav Countries. University of Luton and IOASS, University of York.

Note 26. Amisi, B. (2006) 'An Exploration of the Livelihood Strategies of Durban Congolese Refugees,' UNHCR Working Paper No.123, New Issues in Refugee Research, UNHCR, Geneva.

Note 27. Beer, A., Kearins, B., Pieters, H. (2007) Housing Affordability and Planning in Australia: The Challenge of Policy Under Neo-liberalism, Housing Studies, vol. 22 (1), pp. 11-24.

Note 28. Berry, M. (2006) Housing affordability and the economy: A review of macroeconomic.

Note 29. Audenaert, A., De Clyen, S. H., Vankerckhove, B. (2008). Economic analysis of passive houses and low-energy houses compared with standard houses. Energy Policy.

Note 30. Beer, A., Kearins, B. \& Pieters, H. (2007) Housing Affordability and Planning in Australia: The Challenge of Policy Under Neo-liberalism, Housing Studies, vol. 22 (1), pp. 11-24.

Note 31. Al-Temeemi, A.S. (1995). Climatic design techniques for reducing cooling energy consumption in Kuwaiti houses. Energy and Buildings.

Note 32. Dewit, M and Schenk, H., 1989. Shelter for the poor in India; Issues of low cost housing, Published by Ramesh Jain, Manohar publications, 2/6 Ansari Road, Daryaganj, New Delhi-110002.

Note 33. Ebsen, C., and Ramboll, B., 2000. International review of low-cost sustainable housing projects, Proceedings: Strategies for a Sustainable built environment.

Note 34. Bülow-Hübe, H. (2001). Energy-efficient window systems: Effects on energy use and daylight in buildings.

Note 35. Turner, J.F.C (1976). Housing by people towards autonomy in building environments. Marion Boyars, London.

Note 36. Tiwari, P 2001. Housing and development objectives in India. Habitat international 25, 225-253. Dimson, B (1996). Principles and challenges of sustainable design and construction.

Note 37. Environment 19 (2)Reddy, B, V, V and Jagadish, K, S 2001. Embodied energy of common and alternative building materials and technologies. Energy and Buildings 35, 129-137.

Note 38. Spence.R and Mulligan.H, 1995. Sustainable Development and Construction industry. Habitat international 19 (3), 279-292.

Note 39. Agenda 21 for sustainable construction in developing countries, a discussion document. The international council for research and innovation in building and construction CIB and United Nations Environment Program International Technology Centre UNEP-IETC.

Note 40. Samuel research and consulting company, full report of the UNHCR Shelter Assistance Program 2013.

Note 41. D. Turton and P. Marsden, Taking Refugees for a Ride? The Politics of Refugee Return to Afghanistan, 
Kabul, Afghanistan Research and Evaluation Unit, 2002.

Note 42. Lohse, U., 2002. Housing finance-overview. In UN Habitat (Ed.), Financing adequate shelter for all. UN Habitat, Nairobi: Addressing the Housing Finance Problem in Development Countries. pp: 41-47.

Note 43. Department of Housing, 2003. A Social Housing Policy for South Africa Towards an enabling environment for social housing development, revised draft July 2003.

Note 44. Department of housing, 2004. United Nations Commission for sustainable Development twelfth session 14-30 April 2004, South Africa's progress report Human settlement.

Note 45. Department of Housing, 2005. http://www.housing.gov.za/Content/Strategic\%20Statement.htm, Strategic Statement from the Director General Ms MZ Mpofu.

Note 46. World Commissions for Environment and Development, 1987:23 Jansen, L 2002. The Challenges of sustainable development. Journal of Cleaner Production 11, 231-245.

Note 47. Yuen, B. (Eds.) Sustainable cities in the 21st century, Singapore: National University of Singapore, pp. 131-142. Choguill, C. L. (2007) 'The search for policies to support sustainable housing', Habitat International, vol. 31, pp. 143-149.

Note 48. Gerard Meszaros and Jim Doble. "MetaPatterns: A Pattern Language for Pattern Writing". http://st-www.cs.illinois.edu/patterns/Writing/pattern_index.html.

Note 49. Chakrabarthy, B, K., 1993. National Shelter strategy: A model based approach, Habitat international 17, pp 31-54.

Note 50. Dorst, M, J., and Duijvestein, C, A, J., 2004. Concepts of Sustainable Development, Proceedings of the 2004 International Sustainable Development research conference on 29-30 March, University of Manchester, UK.

Note 51. Choguill, C, L., 1996. Ten Steps to Sustainable Infrastructure, Habitat International, 20, (3), pp 389-404.

Note 52. Mr. Adam, Mr. L.M. Austin, et al. (2000) Guidelines for Human Settlement, Planning and Design, Volume 1. Compiled under the patronage of the Department of Housing by CSIR Building and Construction Technology.

Note 53. Editorial, Learning from the past: international housing policy since 1945- an introduction. Habitat International, 27 (2003) 163-166.

Note 54. Eldmery, I, M., 2002. Towards a participatory loan-supported housing scheme, Helwan New Community, Egypt, Cities, 19, (6), pp 401-408.

Note 55. Elizabeth, L., Adams, C., 2000. Alternative construction- contemporary Natural building Methods, pp 209-235.

Note 56. Emmanuel, R., 2004. Estimating the environmental suitability of wall materials: preliminary results from Sri Lanka, Building and Environment, 39, pp 1253 - 1261.

Note 57. Ashkenas, R., Ulrich D., Jick, T., Kerr., S. (1995) The Boundaryless Organization: Breaking the Chains of Organizational Structure.

Note 58. DIAC (Department of Immigration and Citizenship). 2007b. Settlement Database - Refugee and Humanitarian Entrants 1 July 2006 to 30 June 2007 by Local Government Area. Canberra: DIAC.

Note 59. Krishan, A., Baker, N., Yannas, S., \& Szokolay, S. V. (2001). Climate Responsive Architectute: A design handbook for energy efficient buildings. New Delhi: Tata Mcgraw-Hill.

Note 60. Ghobadian, V., Taghi, N. \& Ghodsi, M.(2008). Tehran: A hot arid climate. In Hyde, R. (Ed), Bioclimatic Housing: Innovative designs for warm climates (pp.173-193). UK \& USA: Earthscan.

Note 61. Berry, M. (2006) Housing affordability and the economy: A review of macroeconomic impacts and policy issues, Australian Housing and Urban Research Institute.

Note 62. Bourdieu, P. (1986) 'The forms of capital', in: J.G. Richardson (Ed) The Handbook of Theory and Research for the Sociology of Education (New York, Greenwood Press), pp. 241- 258.

Note 63. Bramely, G. and Power, S. (2009). Urban form and social sustainability: the role of density and housing type, Environment and Planning B: Planning and Design, 36, 30-48.

Note 64. Burke, T., Pinnegar, S., Phibbs, P., Neske, C., Gabriel, M., Ralston, L. \& Ruming, K. (2007). 
Note 65. Experiencing the housing affordability problem: blocked aspirations, trade-offs and financial hardships, Australian Housing and Urban Research Institute. Burns, L. (2008) Housing Costs and Affordability in Australia, RBA Economics Competition.

Note 66. Reazul Islam Sr. Private Sector Development Specialist, Housing Finance in Afghanistan: Challenges and Opportunities July 2008.

Note 67. Deepa Gopalakrishnan Nair Master of Science in Habitat Technology, Birla Institute of Technology and Science (India) Sustainable-Affordable Housing for the Poor in Kerala.

Note 68. Dewit, M and Schenk, H., 1989. Shelter for the poor in India; Issues of low cost housing, Published by Ramesh Jain, Manohar publications, 2/6 Ansari Road, Daryaganj, New Delhi-110002.

Note 69. Erguden, S., 2001. Low cost housing, Policies and constraints in developing countries. Spatial information for sustainable development, International conference, Nairobi, Kenya.

Note 70. Liming Yao Nottingham Trent University, School of Architecture, Design, and the Build Environment, Nottingham, NG1 4BU, United Kingdom House Price Appreciation And Housing Affordability In Chinese Housing Market.

Note 71. Barnett, R., \& Lowe, S. (1990). Measuring housing need and the provision of social housing. Housing Studies, 5(3), 184-194.

Note 72. Himmelberg, C., Mayer, C., \& Sinai, T. (2005). Assessing high house prices: Bubbles, fundamentals, and misperceptions (No. w11643). National Bureau of Economic Research.

\section{Copyrights}

Copyright for this article is retained by the author(s), with first publication rights granted to the journal.

This is an open-access article distributed under the terms and conditions of the Creative Commons Attribution license (http://creativecommons.org/licenses/by/3.0/). 